\title{
Geochemical Modeling and Statistical Analysis for Groundwater Evolution Assessment in Wadi Qasab, Sohag, Eastern Desert, Egypt
}

\author{
Ehab Zaghlool \\ Hydrogeochemistry Department, Division of Water Resources and Arid Lands, Desert Research Center, Cairo, Egypt \\ Email: ezaghlooldrc@yahoo.com
}

How to cite this paper: Zaghlool, E. (2020). Geochemical Modeling and Statistical Analysis for Groundwater Evolution Assessment in Wadi Qasab, Sohag, Eastern Desert, Egypt. Journal of Geoscience and Environment Protection, 8, 33-61.

https://doi.org/10.4236/gep.2020.89003

Received: August 3, 2020

Accepted: September 5, 2020

Published: September 8, 2020

Copyright $\odot 2020$ by author(s) and Scientific Research Publishing Inc. This work is licensed under the Creative Commons Attribution International License (CC BY 4.0).

http://creativecommons.org/licenses/by/4.0/

\begin{abstract}
Qasab basin is one of the most promising areas for the sustainable development in the Eastern Desert fringes of the Nile Valley, Egypt. The integration between statistical analysis, stable isotopes as well as geochemical modeling tools delineated the geochemical possesses affecting groundwater quality and detected the main recharge source in Qasab basin. The most of groundwater samples are brackish (88\%), while the minority (12\%) of the samples are fresh. The electrical conductivity of groundwater ranged from 1135 to 10,030 $\mu \mathrm{S} / \mathrm{cm}$. The statistical analysis and hydrochemical diagrams suggest that the groundwater quality is mainly controlled by several intermixed processes (rock weathering and agricultural activities). The mineralization of the Pleistocene groundwater is regulated by the rock weathering source, evaporation processes and reverse cation exchange. The isotopic signatures $\left(\delta^{2} \mathrm{H}\right.$ and $\delta^{18} \mathrm{O}$ ) represent two groundwater groups. The first group, is enriched with the isotopic signature of $\delta^{18} \mathrm{O}$, which ranges from $0.9 \%$ to $5.5 \%$. This group is mostly affected by the recent meteoric recharge from the surface water leakage. The second group, is relatively depleted with the isotopic signature of $\delta^{18} \mathrm{O}$, reflecting a palaeo recharge source of colder climate. The $\delta^{18} \mathrm{O} \%$ varies from $-10.1 \%$ to $-6.4 \%$, indicating upward leakage of the Nubian sandstone aquifer through deep seated faults. The inverse geochemical model reflects that the salinity source of the groundwater samples is due to the leaching and dissolution processes of carbonate, sulphate and chloride minerals from the aquifer matrix. This study can demonstrate the hydrochemistry assessment guide to support sustainable development in Qasab basin to ensure that adequate groundwater management can play to reduce poverty and support socioeconomic development.
\end{abstract}

\section{Keywords}

Hydrochemistry, Statistical Analysis, Stable Isotopes, Inverse Geochemical 
Modeling and Qasab Basin, Egypt

\section{Introduction}

Groundwater plays a significant function in the implementation of the sustainable development policies in the desert fringes in the Eastern Desert of Egypt. The over pumping of groundwater without regulator restrictions of the triggers causes the degradation of aquifers and the loss sustainable wise. It contributes to the restrictions in developing proposals in these areas. The depletion of water supplies and the groundwater quality degradation present persistent challenges to the sustainable development and make it necessary to conserve water security through all means. In the study area, the water demand for domestic and industrial sectors was sufficient for the agricultural land in the winter, while in the summer months the percentage of the available water only covers $57 \%$ from the daily needs (Omar \& Moussa, 2016). It decreases by $27 \%$ of water usage by importing food and other indirect products (Gad, 2017). Recently, Sohag Governorate is trying to reclamate the desert fringes East the River Nile in Qasab basin. The main reclamation projects focus along the main channel of Qasab basin, where the farmers depend mainly on groundwater for irrigation; however the aquifer is ill-constraint and there are no sufficient hydrogeological and hydrochemical data about groundwater potentiality or quality. Therefore, the hydrogeological and the hydrogeochemical data about the concerned aquifer should be well investigated in order to provide accurate data for the decision makers for future infrastructure planning as well as consideration of the economic return for cultivating these lands.

The hydrochemical characteristics of the groundwater are used for tracking the groundwater circulation processes in order to identify the processes controlling the groundwater chemistry and geochemical processes affecting groundwater quality. Groundwater chemistry is influenced by the natural factors including the aquifer lithology, geological structure, recharge, geochemical reactions within the aquifer, and the rate of groundwater flow from recharge to discharge areas through its passage (Appelo \& Postma, 2005), in addition the anthropogenic practices such as groundwater over pumping, unregulated drilling of wells as well as the unlimited agricultural and industrial activities (Huang et al., 2013). Understanding aquifer geochemistry and recognizing the causes of the depletion of groundwater are critical for controlling and enhancing the management of the groundwater resources (Trabelsi \& Zouari, 2019).

The multivariate statistical analysis techniques are powerful in the investigations of groundwater chemistry. This technique helps to classify groundwater and delineate major mechanisms influencing groundwater chemistry (Cloutier et al., 2008). Geochemical modeling is commonly used for the investigation of water-rock interface. It aims to delineate the chemical reactions occurring along 
a flow path. The account for water chemistry changes between one or a mixture of initial and final water compositions based on mole transfers of phases (Trabelsi \& Zouari, 2019). The isotopic ratio of oxygen $\left(\delta^{18} \mathrm{O}\right)$ and hydrogen $\left(\delta^{2} \mathrm{H}\right)$ in groundwater is important for providing information on the groundwater recharge source and salinization mechanism (Marković et al., 2020). The integration between hydrochemical interpretation diagrams, multivariate statistical analysis of groundwater chemistry and Inverse geochemical models as well as environmentally stable isotopes $\left({ }^{18} \mathrm{O}\right.$ and $\left.{ }^{2} \mathrm{H}\right)$ constitutes effective approach to assessment the geochemical process and the water quality criteria in the studied systems (Singh et al., 2017; Trabelsi \& Zouari, 2019; Eissa et al., 2019).

The main objective of this study is to identify the hydrochemical characteristics, the processes controlling the groundwater quality and the groundwater origin as well as assessment of the main groundwater aquifers for irrigation purposes in Qasab basin in the Eastern Desert fringes of Sohag Governorate region, Egypt.

\section{Study Area Description}

\subsection{General Setting}

Qasab basin is situated in the Eastern Desert south east of Sohag Governorate, Egypt between longitude $31.85^{\circ} \mathrm{E}$ to $32.3^{\circ} \mathrm{E}$ and $26.15^{\circ} \mathrm{N}$ to $26.45^{\circ} \mathrm{N}$, covers about $2000 \mathrm{~km}^{2}$ (Abdel Moneim, 2005). Qasab basin is bounded by the River Nile from the west and the Eastern Desert hilly from the east (Figure 1). The study region belongs to Egypt's arid zone, which is marked by long and hot summer, cold winter, low rainfall and high evaporation. The maximum temperature reaches to $36.9^{\circ} \mathrm{C}$ in the summer and the minimum is $19.7^{\circ} \mathrm{C}$ in the winter (Farrag et al., 2015). The mean annual rainfall over the Sohag governorate reaches about 1.2 $\mathrm{mm}$, while the high rate of potential annual evaporation $2395 \mathrm{~mm} /$ year (Gomaa, 2006).

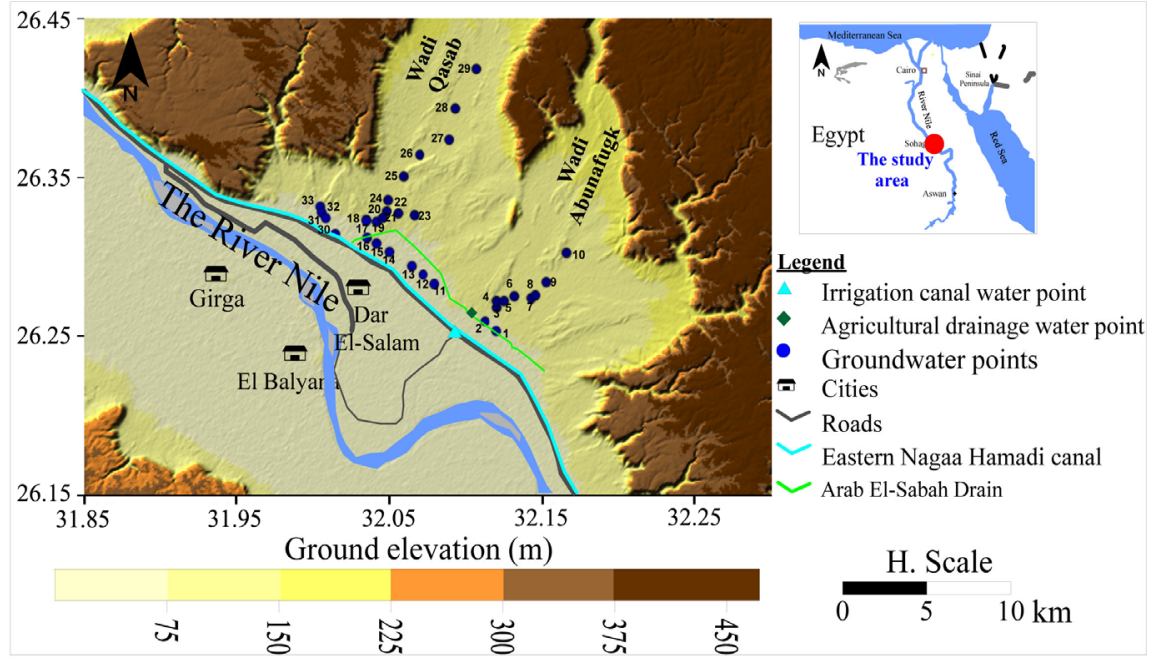

Figure 1. Topographic map of the study area with water samples locations. 


\subsection{Geomorphological, Geological and Hydrogeological Setting}

Geomorphologically, Qasab basin is characterized by three main geomorphological units. The first unit is the Nile flood plain of the cultivated lands. Its altitudes range from 55 to $65 \mathrm{~m}$ above the sea level (masl). This unit consists mainly of clay and silt sediments. The second unit is the low desert land area of old alluvial plain which is amongst the Nile flood plain and the Eocene limestone plateau. Its altitude ranges from 70 to $140 \mathrm{~m}$ and gentle westward slope. The third unit is the Eocene limestone plateau. This unit occupies the eastern parts of the study area and forms the higher relief feature. Its altitude ranges from 200 to 375 m (Youssef et al., 2011).

Geologically the outcrops of the study area are ranging in ages from Eocene to Quaternary (Figure 2(a)). The lithostratigraphic units in the investigated region are: 1) The Eocene rocks are represented by Thebes formation. This formation constitutes the foot of the eastern limestone scarp, extending from Wadi Abu Nafoukh in the south to Awlad El Sheikh in the north. It consists of massive and
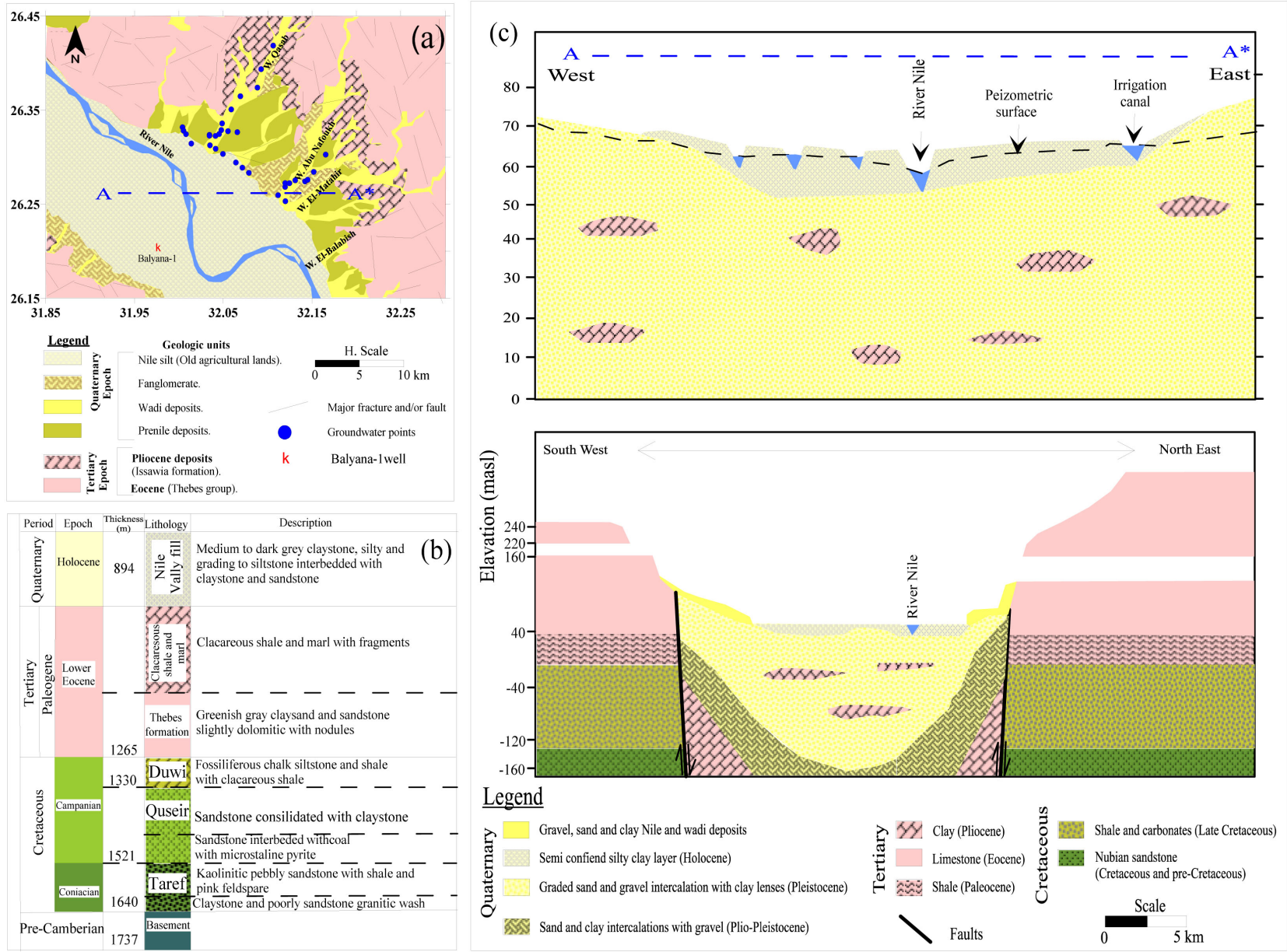

Figure 2. (a) Geologic map of Wadi Qasab area (after E.G.P.C., 1987); (b) Stratigraphic column of Balyana-1 well drawn based on the report of the borehole (after Ganoup El-Wadi Petroleum Company, 1994); (c) Hydrogeological cross section in Qasab basin (Gomaa, 2006) and general Hydrogeological cross section of Sohag area (after RIGW Egypt, 1997; Ahmed, 2009). 
laminated limestone beds with the flint bands and marl (Said, 1960); 2) Late Pliocene or Early Pleistocene is represented by Issawia formation. It composes of lacustrine deposits of carbonate and clastic facies (Issawi et al., 1978; Omer, 1996); and 3) The Quaternary deposits are presented the Pleistocene and the Holocene deposits. This formation is widely distributed on both the surface and subsurface along the Nile valley (Said, 1975, 1981). The subsurface units were identified via the Balyana-1well geological report located at the west to the study area (Figure 2(b)). The subsurface units show that pre-Cambrian granite is followed by Taref formation. Taref formation consists of kaolinitic pebbly sandstone with shale and pink feldspar. This formation is overlain Qusayr formation. Qusayr formation is mainly consists of pebbly sandstone silt and shale. This unit is overlain by Duwi formation which consists of argillaceous, fossiliferous chalk while the lower unit is dominated by siltstone and shale sequences with thin calcareous sandstone interbeds. Duwi formation is overlain by the lower portion of the lower Eocene (Thebes formation) forms the plateau surrounding the Nile valley. At the top of the subsurface section the Nile Valley fill is dominated by pebbly sandstone, siltstone, and shale. Most of these lithologies are developed during the Eonile phase (Pliocene time) (Ghazala et al., 2018). By the beginning of Pleistocene the local depressions were left receiving water only during rainy storms, and accumulated lacustrine sediments (Issawi et al., 1978). The Late Pleistocene (Dandara Formation) is represented by flood plain deposits. This deposits composed of fine silica clastic beds (siltstone, claystone, and fine-grained sandstones) and accumulated on the Nile River banks. The Holocene and recent sediments consist of cultivated lands were formed by silts and clays (Ahmed, 1980).

Hydrgeologically the Pleistocene alluvial aquifer represents the main aquifer in the Nile valley. It mainly composes of sands and gravels with clay lenses. It overlain by Holocene aquitard (Nile silt and clay) and underlain by marine Pliocene clay aquiclude of very low permeability (Gomaa, 2006) (Figure 2(c)). The aquifer thickness varies between 50 and $260 \mathrm{~m}$ (Gomaa, 2006). Generally, the aquifer thickness vanishes toward the limestone plateau and faulted against Eocene limestone from east to west (Figure 2(c)). The Pleistocene aquifer presents, semiconfined conditions in floodplain areas and unconfined conditions in the desert fringes due to the absent of the silt clay layer (Said et al., 2020). The average hydraulic conductivity is about $70 \mathrm{~m}$ /day (Attia et al., 1986). The aquifer is recharged by the seepage from the surface water and the excess irrigation water. These waters seep vertically under the cultivated lands and flow horizontally toward the desert fringes (Gomaa, 2006). The groundwater flow in Qasab basin is towards the River Nile. The lowest groundwater table is close to the River Nile $53 \mathrm{~m}$ (masl) and the highest at the valley fringes $67 \mathrm{~m}$ (masl) (Ahmed \& Ali, 2009). Accordingly, the River Nile acts as discharge system of the Pleistocene aquifer, as well as seepage into the agricultural drains and the irrigation canals during water restriction in the winter period (Said et al., 2020). 


\section{Materials and Methods}

\subsection{Water Sampling and Analytical Techniques}

\section{Sampling Procedure}

Thirty five water samples were collected from the study area during November 2018. Thirty three are groundwater samples represented the Pleistocene aquifer, one sample is from the irrigation canal (Eastern Nagaa Hamadi canal) and one sample is from the agricultural drain (Arab El-Sabah drain) (Figure 1). Fifty $\mathrm{ml}$ of water samples was stored after acidification to $\mathrm{pH}<2$ with $\mathrm{HNO}_{3}$ for cations and trace element analysis. A five hundred $\mathrm{ml}$ of water samples was stored for anion measurements without acidification. Fifty $\mathrm{ml}$ of water samples was stored for stable isotopes. All samples were stored in clean, high-polyethylene bottles and wrapped in strips to ensure no leakage.

Field Measurements

Both $\mathrm{EC}$ and $\mathrm{pH}$ were measured in situ by using Orion portable meters.

\section{Laboratory Measurements}

The concentrations of Carbonate and bicarbonate were detected by titration using $\mathrm{H}_{2} \mathrm{SO}_{4}(0.01 \mathrm{~N}) . \mathrm{Ca}^{2+}, \mathrm{Mg}^{2+}, \mathrm{Na}^{+}, \mathrm{K}^{+}, \mathrm{SO}_{4}^{2-}$ and $\mathrm{Cl}^{-}$were measured by using ion chromatography system (Dionex, ICS-1100). The quality assurance for all water samples (E.B.\%) was within $\pm 2 \%$ (Appelo \& Postma, 2005). TDS values were obtained through the calculation method by adding all detected dissolved solid materials (in $\mathrm{mg} / \mathrm{l}$ ) reported in the analytical statement beside converting identified bicarbonate to carbonate $(\mathrm{mg} / \mathrm{l}) \mathrm{CO}_{3}=\left((\mathrm{mg} / \mathrm{l}) \mathrm{HCO}_{3} / 2.03\right)$. Heavy and trace elements ( $\mathrm{Al}, \mathrm{Cd}, \mathrm{Cr}, \mathrm{Cu}, \mathrm{Fe}, \mathrm{Mn}, \mathrm{Ni}, \mathrm{Pb}$, and $\mathrm{Zn}$ ) were measured by using inductive coupled plasma mass spectrometry (ICP, POEMSIII, thermo Jarrell elemental company USA), using $1000 \mathrm{mg} / \mathrm{l}$ (Merck) Stock standard solutions. The analysis of the major and trace elements as well as heavy metals were carried out in Hydrogeochemistry laboratories, Desert Research Center, Cairo, Egypt. ${ }^{18} \mathrm{O}$ and ${ }^{2} \mathrm{H}$ for nine groundwater samples and two surface water samples (the irrigation canal and agricultural drainage) were carried out at the Stable Isotope Unit, Institute of Material Science, NCSR "Demokritos", Athens, Greece. $\delta^{18} \mathrm{O} \%$ and $\delta^{2} \mathrm{H} \%$ were conducted according to the isotopic methods for ${ }^{18} \mathrm{O}$ (Epstein \& Maida, 1953) and ${ }^{2} \mathrm{H}$ (Coleman et al., 1982).

\subsection{Data Analysis}

The geographical and the groundwater quality distribution maps were carried out using Geographic Information System (GIS) software package Global mapper 11 and golden software surfer 12. Hydrochemical diagrams (Sulin, 1946; Piper, 1953; Gibbs, 1970) were performed using Aqua Chem V, 3.7.

\section{Statistical Analysis}

A multivariate statistical method was performed by using SPSS V.16 software. The relations between groundwater chemistry variables were determined by Pearson correlation coefficient and Hierarchical cluster analysis (HCA). These effective tools can be used for identifying the hydrorgeochemical processes that 
controlling groundwater chemistry (Davis, 2002).

\section{Stable Isotopes}

Water compositions of ${ }^{18} \mathrm{O}$ and ${ }^{2} \mathrm{H}$ can be used for investigating the salinization source of groundwater through flow processes, delineating the groundwater origins and the recharge source. Both $\delta^{18} \mathrm{O}$ and $\delta^{2} \mathrm{H}$ values are expressed in $\delta^{18} \mathrm{O} \%$ and $\delta^{2} \mathrm{H} \%$. Delta values $(\delta)$ are defined by $\delta \%$ o $=(\mathrm{R}$ sample/R standard $)$ $\times 1000$ and $\mathrm{R}={ }^{18} \mathrm{O} /{ }^{16} \mathrm{O}$ or $\mathrm{D} / \mathrm{H}$, with the standard SMOW (standard mean ocean water). The relations amongst $\delta^{18} \mathrm{O} \%$ and $\delta^{2} \mathrm{H} \%$ and TDS and $\delta^{18} \mathrm{O} \%$ are used for delineating the groundwater recharge source (palaeo recharge or recent precipitation recharge) that the stable isotopic composition of the precipitation in the past ages varies from the present precipitation (Gat, 1981). The Global meteoric water line (GMWL) represents the present-day global precipitation according to this relation $\delta^{2} \mathrm{H} \%$ o $=8 \delta^{18} \mathrm{O} \%$ o 10 (Craig, 1961).

\section{Inverse Geochemical Modelling}

The saturation indices for the groundwater samples in the study area were computed using the inverse geochemical model NETPATH 2.0 (Plummer et al., 1994), according to the equation that was suggested by Lloyd and Heathcode (1985). When the saturation index (SI) value is negative, it indicates that groundwater is unsaturated with respect to that particular mineral. When SI index is positive, it indicates that the groundwater is being saturated with respect to the particular mineral phase (Langmuir, 1997).

\section{Groundwater Evaluation for Irrigation Purposes}

In this study; the groundwater samples were evaluated for the irrigation purposes on the basis of Irrigation Water Quality Index (IWQI) (Spandana et al., 2013). According to Ayers and Westcot (1985) and Rowe and Abd el-Magid (1995) the acceptable parameters of the irrigation water quality requirements were used. The American classification diagram (US Salinity Laboratory Staff, 1954) had developed a system for classifying the irrigation water quality relating to the graphical analysis.

\section{Results and Discussions}

\subsection{Physicochemical Parameters, Major Ions Distribution and Trace Metal Contamination}

The Pleistocene groundwater samples in the investigated area were neutral to slight alkaline with $\mathrm{pH}$ levels ranging from 7.1 to 8.2 (Table 1). These may be due to the dissolution of alkaline cations or bicarbonates from the mineralogical source or dissolved hydroxide the water resources. Electrical conductivity (EC) ranged from 1135 to $10,030 \mu \mathrm{S} / \mathrm{cm}$ with the mean value $3499 \mu \mathrm{S} / \mathrm{cm}$ (Table 1 ). The majority were categorized as a medium salt enrichment (52\% of samples, $1500<\mathrm{EC}<3000 \mu \mathrm{S} / \mathrm{cm}$ ). $42 \%$ of the samples were high salt enrichment (EC > $3000 \mu \mathrm{S} / \mathrm{cm}$ ). $6 \%$ of water samples were low salt enrichments (EC $<1500$ $\mu \mathrm{S} / \mathrm{cm})$. The groundwater in Qasab basin can be divided into two classes based on TDS values. The majority of the ground water samples $(88 \%)$ are brackish 
Table 1. Physico-chemical parameters, major ions concentrations and descriptive statistics for the water samples in Qasab basin.

\begin{tabular}{|c|c|c|c|c|c|c|c|c|c|c|c|c|c|c|}
\hline \multirow{2}{*}{ No. } & \multirow{2}{*}{$\begin{array}{l}\text { Long } \\
\text { (E) }\end{array}$} & \multirow{2}{*}{ (N) } & \multirow{2}{*}{$\mathrm{pH}$} & \multirow{2}{*}{$\begin{array}{c}\text { EC } \\
\mu \mathrm{S} / \mathrm{cm}\end{array}$} & \multirow{2}{*}{$\begin{array}{c}\text { TDS } \\
(\mathrm{mg} / \mathrm{l})\end{array}$} & \multicolumn{4}{|c|}{ Cations (mg/l) } & \multicolumn{4}{|c|}{ Anions $(\mathrm{mg} / \mathrm{l})$} & \multirow{2}{*}{$\begin{array}{c}\text { E.B., } \\
\%\end{array}$} \\
\hline & & & & & & $\mathrm{Ca}^{2+}$ & $\mathrm{Mg}^{2+}$ & $\mathrm{Na}^{+}$ & $\mathrm{K}^{+}$ & $\mathrm{CO}_{3}^{2-}$ & $\mathrm{HCO}_{3}^{-}$ & $\mathrm{SO}_{4}^{2-}$ & $\mathrm{Cl}^{-}$ & \\
\hline 1 & 32.12 & 2531 & 8 & 5 & 9 & 177 & 102 & 908 & 13 & 0 & 2 & 38 & 289 & 1.4 \\
\hline 2 & 1117 & 26.2595 & 8 & 4100 & 2400 & 127 & 88 & 593 & 13 & 0 & 127 & 503 & 013 & -1.8 \\
\hline 3 & 32.1197 & 26.2683 & 7.9 & 1135 & 701 & . & 29 & 135 & 6 & 12 & 77 & 25 & 134 & 0.6 \\
\hline 4 & 32.1197 & 26.2723 & 8.2 & 5700 & 3466 & 175 & 101 & 940 & 3 & 12 & 85 & 902 & 1291 & 0.9 \\
\hline 5 & 32.1246 & 26.2723 & 8 & 1876 & 1114 & 95 & 47 & 240 & 3 & 0 & 1 & 03 & 328 & 0.9 \\
\hline 6 & 32.1311 & 26.2753 & 7.9 & 1595 & 991 & 85 & 38 & 210 & 4 & 18 & 4 & 96 & 223 & -1.0 \\
\hline 7 & 1421 & 26.2742 & 8 & 2376 & 1379 & 105 & 49 & 30 & 3 & 12 & 28 & 80 & 536 & 0.6 \\
\hline 8 & 32.1451 & 26.2759 & 7.9 & 2189 & 1280 & 80 & 42 & 320 & 3 & 0 & 171 & 302 & 447 & -0.5 \\
\hline 9 & 32.1519 & 26.2843 & 8.2 & 1996 & 1140 & 79 & 40 & 280 & 3 & 12 & 140 & 268 & 387 & 0.8 \\
\hline 10 & 32.1654 & 26.3027 & 7.6 & 2130 & 1235 & 83 & 39 & 310 & 3 & 0 & 128 & 89 & 447 & 0.5 \\
\hline 11 & 0788 & 26. & 7 & 3100 & 1884 & 9 & 71 & 500 & 12 & 0 & 242 & 2 & 671 & 2.0 \\
\hline 12 & 5 & 26.2 & 7.8 & 5570 & 3365 & 65 & 10 & 904 & 17 & 0 & & 28 & 1272 & 0.5 \\
\hline 13 & 32.0642 & 26.2942 & 7.8 & 1804 & 1104 & 83 & 37 & 231 & 15 & 0 & 17 & 439 & 242 & -0.8 \\
\hline 14 & 32.0496 & 26.3034 & 7.6 & 1753 & 1077 & 78 & 36 & 224 & 14 & 0 & 119 & 434 & 233 & -1.8 \\
\hline 15 & 32.0414 & 26.3089 & 7.7 & 1350 & 795 & 77 & 20 & 150 & 11 & 0 & 205 & 247 & 178 & -1.7 \\
\hline 16 & 0 & 2 & 7 & 5580 & 3 & 171 & 100 & 2 & 18 & 0 & & 1 & 200 & 4 \\
\hline 17 & 344 & 26. & 7.8 & 550 & 5118 & 173 & 110 & 1550 & 8 & & & 1141 & 2036 & 0.5 \\
\hline 18 & 344 & 26.3 & 7.9 & 2301 & 1366 & 7 & 33 & 90 & 3 & 12 & 19 & 76 & 467 & 1.4 \\
\hline 19 & 32.0412 & 26.3225 & 7.9 & 2016 & 1204 & 77 & 33 & 320 & 3 & 12 & 165 & 270 & 407 & 0.8 \\
\hline 20 & 32.0453 & 26.3245 & 7 & 427 & 2514 & 100 & 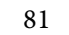 & 80 & 5 & 0 & & 47 & 1117 & 0.2 \\
\hline 21 & 478 & & 7.8 & 3 & & 11 & & & 3 & ( & & & 869 & .6 \\
\hline 22 & 553 & 26.3275 & 7.1 & 3000 & 1844 & 9 & 62 & 480 & 4 & ( & & 96 & 765 & -0.8 \\
\hline 23 & 658 & 26 & 8.1 & 2639 & 1505 & 9 & 47 & 00 & 3 & 12 & 9 & 76 & 616 & 1.7 \\
\hline 24 & 3 & & 8.1 & & 1 & 80 & 33 & 0 & 3 & 0 & & 1 & 457 & 0.6 \\
\hline 25 & 32.0589 & 26.3507 & 7.8 & & & 73 & 34 & 320 & 2 & $1 \varepsilon$ & & 66 & 407 & 0.3 \\
\hline 26 & 32.0693 & 26.3647 & 7.8 & 2479 & 1462 & 8 & 39 & 390 & 3 & ( & 77 & 82 & 576 & -1.2 \\
\hline 27 & 32.0885 & 26 & 7.8 & 156 & 944 & 76 & 36 & 0 & 2 & c & 110 & 77 & 268 & -0.8 \\
\hline 28 & 32.0927 & 26.3935 & 7.7 & 3160 & 1911 & 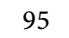 & 00 & 510 & 2 & 0 & 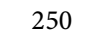 & 06 & 706 & 0.1 \\
\hline 29 & 32.1062 & 26.4185 & 7.6 & 2762 & 1579 & 102 & 40 & 430 & 2 & 0 & & 93 & 586 & 0.7 \\
\hline 30 & 32.0139 & 26.3144 & 7.5 & 4580 & 2787 & 183 & 135 & 601 & 14 & 0 & 41 & 708 & 1027 & -1.0 \\
\hline 31 & 32.0080 & 26.3244 & 7.9 & 6230 & 3555 & 262 & 191 & 746 & 18 & 0 & 7 & 928 & 1275 & 1.6 \\
\hline 32 & 32.0052 & 26.3281 & 7.5 & 10030 & 5893 & 322 & 214 & 1520 & 28 & 0 & 96 & 1261 & 2451 & 0.9 \\
\hline 33 & 32.0041 & 26.3317 & 7.4 & 6090 & 3609 & 264 & 195 & 761 & 18 & 0 & 236 & 932 & 1321 & 1.8 \\
\hline. $\mathrm{d}$ & 32.1029 & 26.2625 & 0 & 2492 & 1355 & o & JJ & 310 & 4 & 0 & 220 & 344 & 408 & 0.2 \\
\hline
\end{tabular}




\section{Continued}

\begin{tabular}{|c|c|c|c|c|c|c|c|c|c|c|c|c|c|c|}
\hline I.c & 32.0928 & 26.2541 & 8.3 & 407 & 221 & 43 & 15 & 13 & 2 & 18 & 92 & 49 & 30 & 0.5 \\
\hline R.w & - & - & 6.9 & 128 & 69 & 12 & 6 & 4 & 0.2 & 0 & 40 & 17 & 11 & -1.5 \\
\hline \multicolumn{3}{|c|}{ Minimum } & 6.8 & 1135 & 701 & 70 & 29 & 130 & 2 & 0 & 85 & 226 & 134 & -1.9 \\
\hline \multicolumn{3}{|c|}{ Maximum } & 8.2 & 10030 & 5893 & 322 & 214 & 1550 & 28 & 18 & 273 & 1261 & 2451 & 2.0 \\
\hline \multicolumn{3}{|c|}{ Mean } & 7.8 & 3499 & 2077 & 123 & 72 & 526 & 8 & 4 & 167 & 496 & 765 & 0.4 \\
\hline \multicolumn{3}{|c|}{ Std. Deviation } & 0.3 & 2139 & 1268 & 63 & 50 & 351 & 7 & 6 & 54 & 294 & 538 & 1.0 \\
\hline
\end{tabular}

EC: Electrical conductivity TDS: Total dissolved solids; E.B.: The quality assurance for water samples; A.d: Agricultural drain; I.c: Irrigation canal; R.w: Rain water.

water $(1000>$ TDS $<10,000 \mathrm{mg} / \mathrm{l})$, while the minority $(12 \%)$ of the samples are fresh water (TDS < $1000 \mathrm{mg} / \mathrm{l}$ ) (Freeze \& Cherry, 1979). The salinity distribution map shows that the salinity of the groundwater increases towards the south-west direction influenced by groundwater and geological materials interaction that it flows through. The seepage from the surface water (the Irrigation canal and the agricultural drain) contributed the variation of TDS values of the Pleistocene groundwater (Figure 3).

The amount of $\mathrm{Ca}^{2+}$ in the groundwater samples varies from 70.3 to 322.1 $\mathrm{mg} / \mathrm{l}$ with mean average $122.6 \mathrm{mg} / \mathrm{l}$. Generally the source of $\mathrm{Ca}^{2+}$ in the groundwater is from the dissolution of carbonate minerals (aragonite, calcite $\left(\mathrm{CaCO}_{3}\right)$ and dolomite $\left.\left(\mathrm{CaMg}\left(\mathrm{CO}_{3}\right)_{2}\right)\right)$. The dissolution of gypsum $\left(\mathrm{CaSO}_{4} \cdot 2 \mathrm{H}_{2} \mathrm{O}\right)$ considered one of the main source of $\mathrm{Ca}^{2+}$ at the old agricultural lands due to the returned irrigation water with fertilizer rich. $\mathrm{Mg}^{2+}$ concentration in the groundwater samples varies from 28.9 to $213.5 \mathrm{mg} / \mathrm{l}$ with mean average $72.3 \mathrm{mg} / \mathrm{l}$. Dolomite $\left(\mathrm{CaMg}\left(\mathrm{CO}_{3}\right)_{2}\right)$ dissolution is one of the main source of $\mathrm{Mg}^{2+}$ in groundwater samples (Table 1). The distribution map of $\mathrm{Ca}^{2+}$ and $\mathrm{Mg}^{2+}$ (Figure 3) reflects the same direction of concentration increase. The concentration of $\mathrm{Ca}^{2+}$ and $\mathrm{Mg}^{2+}$ increases towards the south-west direction. This direction reflects the contribution of anthropogenic activities (mainly agricultural activities) and the recharge from the agricultural drain. The concentration of $\mathrm{Na}^{+}$varies from 130.4 to $1550.0 \mathrm{mg} / \mathrm{l}$ with the mean average 525.9 and $7.9 \mathrm{mg} / \mathrm{l}$ (Figure 4). The concentration of $\mathrm{Na}^{+}$increase towards the limestone platue in the north of Wadi Qasab reflecting the dissolution of halite mineral ( $\mathrm{NaCl})$ (Figure 3), beside the base exchange in the old cultivated lands.

$\mathrm{HCO}_{3}^{-}$concentration in the groundwater samples is less than $272.6 \mathrm{mg} / \mathrm{l}$. The concentration of $\mathrm{HCO}_{3}^{-}$is high in the desert fringes of Wadi Qasab due to the dissolution of carbonate minerals. $\mathrm{SO}_{4}^{2-}$ concentration varies from 225.5 to $1260.8 \mathrm{mg} / \mathrm{l}$. The concentration of $\mathrm{SO}_{4}^{2-}$ increases towards the old cultivated lands due to gypsum dissolution as well as the agricultural activities (addition of sulphate fertilizers to the soils). $\mathrm{Cl}^{-}$concentration in the groundwater samples varies from 764.9 to $2450.9 \mathrm{mg} / \mathrm{l}$ (Table 1). The concentration of $\mathrm{Cl}^{-}$increases in the study area as same as the increasing direction of $\mathrm{Na}^{+}$due to the dissolution of halite mineral $(\mathrm{NaCl})$ (Figure 3 ). 


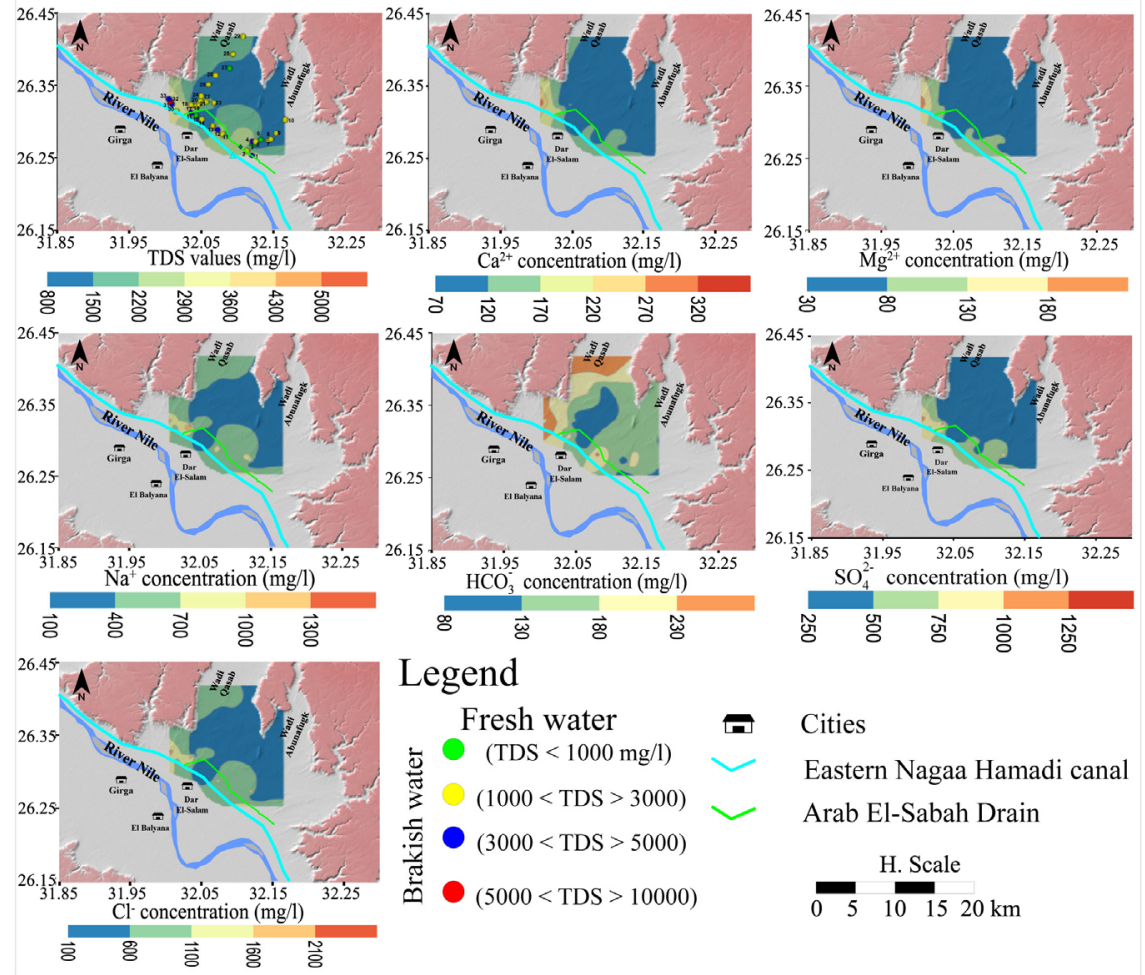

Figure 3. Spatial distribution of TDS and major ions $(\mathrm{mg} / \mathrm{l})$ for the Pleistocene groundwater samples in Qasab basin.

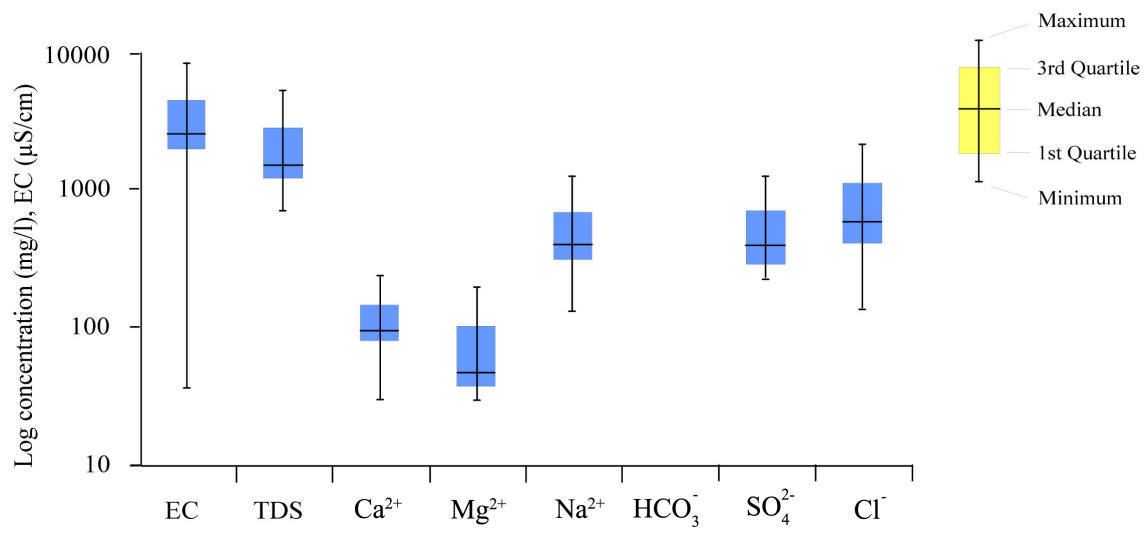

Figure 4. Boxplot representation for EC, TDS, major cations and anions (mg/l) for the Pleistocene groundwater samples in Wadi Qasab.

The abundance of the cations in the study area for the majority of the groundwater samples $(67 \%)$ is in order $\mathrm{Na}^{+}>\mathrm{Ca}^{2+}>\mathrm{Mg}^{2+}$ where the minority $(33 \%)$ are in the order $\mathrm{Na}^{+}>\mathrm{Mg}^{2+}>\mathrm{Ca}^{2+}$. The lowest concentration of $\mathrm{Ca}^{2+}$ and $\mathrm{Mg}^{2+}$ comparing with $\mathrm{Na}^{+}$may be due to the cation exchange processes which indicate the dominance of alkalis over the alkali earth elements. The abundance of the anions for the majority of the groundwater samples (91\%) is in order $\mathrm{Cl}^{-}>$ $\mathrm{SO}_{4}^{2-}>\mathrm{HCO}_{3}^{-}$where the minority $(9 \%)$ are in the order $\mathrm{SO}_{4}^{2-}>\mathrm{Cl}^{-}>\mathrm{HCO}_{3}^{-}$. This reflects the final stage of the groundwater evolution and the effect of leach- 
ing and dissolution of terrestrial and marine salts.

Trace elements concentrations ( $\mathrm{Al}, \mathrm{Cd}, \mathrm{Cr}, \mathrm{Cu}, \mathrm{Fe}, \mathrm{Mn}, \mathrm{Ni}, \mathrm{Pb}$, and $\mathrm{Zn}$ ) (Table 2) reflects some of the water samples are above the drinking water guideline $(0.2,0.003,0.05,2,0.3,0.4,0.02,0.01$ and 3 respectively) WHO (2011). 48\% of the groundwater samples are contaminated in respect to $\mathrm{Al}, 52 \%$ in respect to $\mathrm{Cr}, 39 \%$ in respect to Fe. $29 \%$ of the groundwater samples are contaminated in respect to $\mathrm{Pb}$. The agricultural drain sample is contaminated in respect to $\mathrm{Al}, \mathrm{Cr}$, $\mathrm{Fe}$ and $\mathrm{Pb}$. The wide variation of Fe concentration suggests that its content is controlled by several intermixed processes. The significant positive relation between Fe and Mn (0.81) indicate the Fe source may be attributed to rock weathering, where the Pleistocene deposits (water bearing formation) were containing ferromagnesian minerals representing the source of $\mathrm{Fe}$ and $\mathrm{Mn}$ in the groundwater (Melegy et al., 2013). The positive correlation between Fe with Al, $\mathrm{Cr}$ and $\mathrm{Pb}(0.58,0.42$ and $0.51 \mathrm{mg} / \mathrm{l}$ respectively) may be attributed to the agricultural activities reflects another source of groundwater contamination in respect to Fe.

\subsection{Water Type and Groundwater Origin}

The ions concentrations of the water samples in Qasab basin are plotted on Piper's diagram (Figure 5). All of the groundwater samples are located in the subarea-7 reflect that the chemical characteristics of the groundwater are dominated by primary salinity as well as alkalis and strong acids ( $\mathrm{Na}-\mathrm{Cl}$ type). The hydrochemical facies of almost all the groundwater samples belong to alkaline water with prevailing sulfate and chloride. This reflects marine facies due to the dissolution of carbonate minerals. These minerals were transported by weathering from the Eocene limestone plateau. The presence of the agricultural drain water sample in the same area with the groundwater samples may reflect the influence of the groundwater wells closed to the agricultural drainage system by drainage water.

The relation between $\mathrm{r} \mathrm{Cl}^{-}-\mathrm{r}\left(\mathrm{Na}^{+}+\mathrm{K}^{+}\right)$with $\mathrm{Mg}^{2+}$ and $\mathrm{r}\left(\mathrm{Na}^{+}+\mathrm{K}^{+}\right)-\mathrm{r} \mathrm{Cl}^{-}$ with $\mathrm{SO}_{4}^{2-}$ in meq\% unit are plotted on Sulin diagram (Figure 6). For the interpretation of the origin of the groundwater in the study area (marine or meteoric water), it is clear that the majority of the groundwater samples (76\%) are located in old meteoric water area $\left(\mathrm{Na}_{2} \mathrm{SO}_{4}\right)$. The minority of the samples $(24 \%)$ are located in recent marine water $\left(\mathrm{MgCl}_{2}\right) \cdot \mathrm{MgCl}_{2}$ reveals that the dissolution of the marine salts from the Eocene limestone plateau (Abdulhady et al., 2018). This may indicate that mixing of the old meteoric and marine origin of the groundwater and/or the groundwater is mixed with the upward leakage from the deep aquifer (Abdel Moneim et al., 2015).

The groundwater samples in the study area are characterized by two assemblages of the combination salts:

Assemblage I: $\mathrm{NaCl}-\mathrm{Na}_{2} \mathrm{SO}_{4}-\mathrm{MgSO}_{4}-\mathrm{CaSO}_{4}-\mathrm{Ca}\left(\mathrm{HCO}_{3}\right)_{2}$

Assemblage II: $\mathrm{NaCl}-\mathrm{MgCl}_{2}-\mathrm{MgSO}_{4}-\mathrm{CaSO}_{4}-\mathrm{Ca}\left(\mathrm{HCO}_{3}\right)_{2}$ 


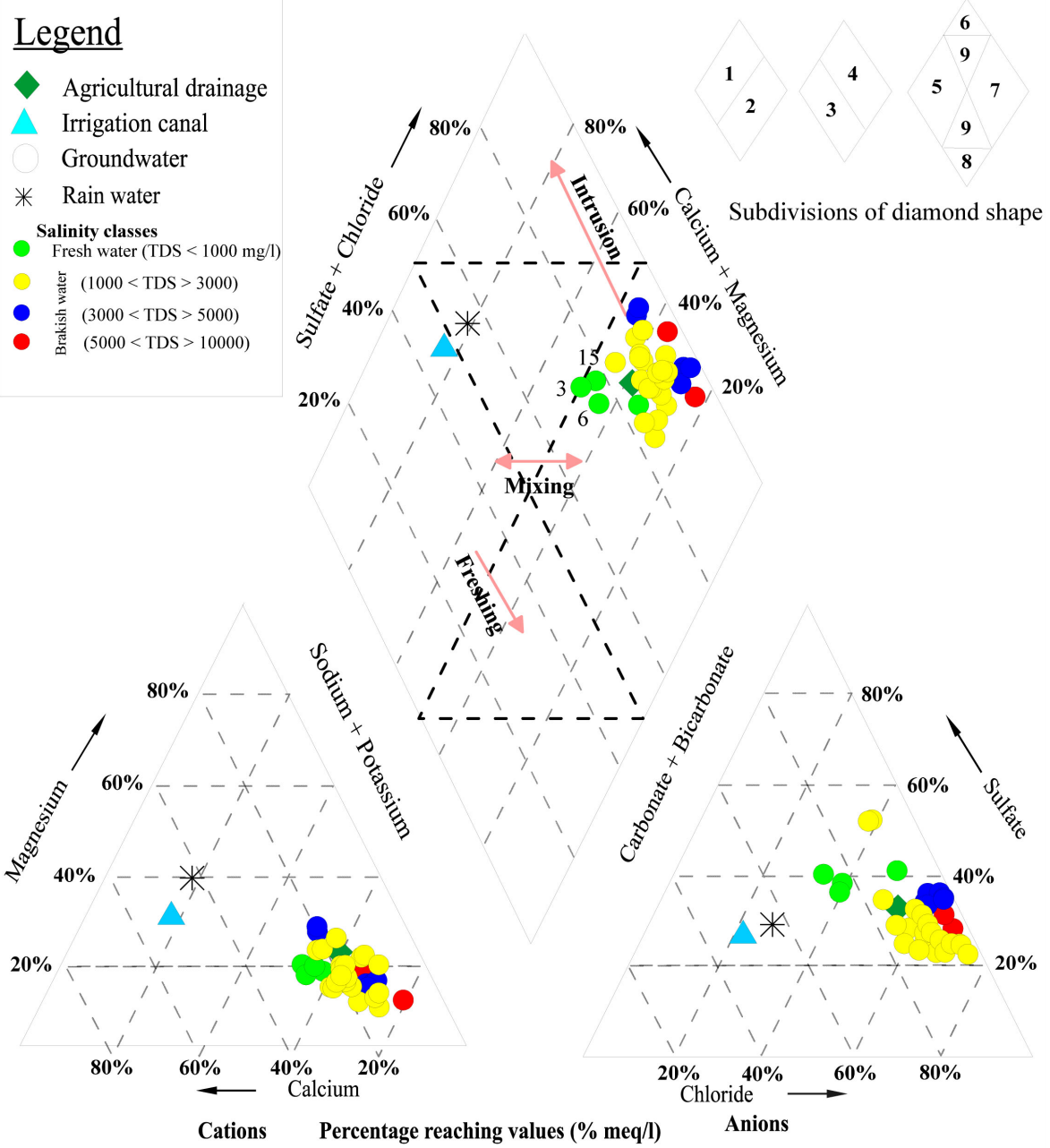

Figure 5. Piper's diagram for the water samples in Qasab basin.

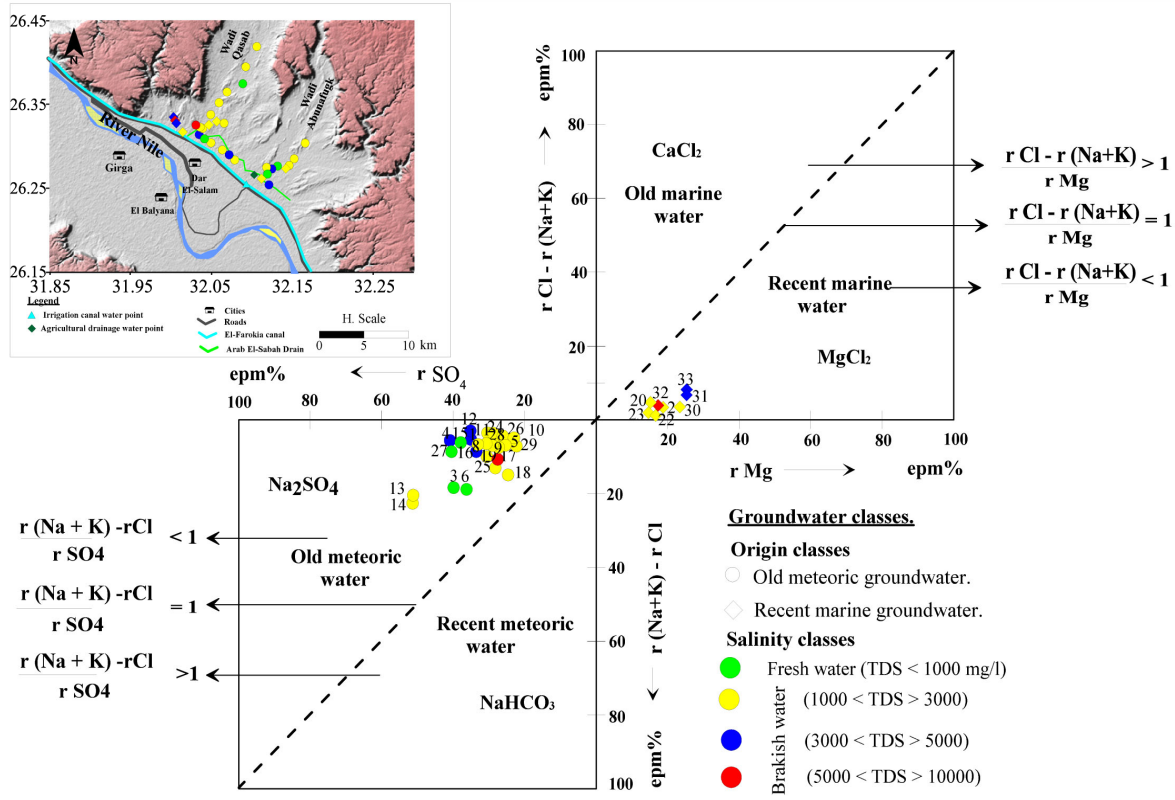

Figure 6. Sulin diagram for the Pleistocene groundwater samples in Qasab basin. 
Table 2. Trace and heavy metal concentrations (mg/l) for the water samples in Qasab ba$\sin$.

\begin{tabular}{|c|c|c|c|c|c|c|c|c|c|}
\hline No. & $\mathrm{Al}$ & $\mathrm{Cd}$ & $\mathrm{Cr}$ & $\mathrm{Cu}$ & $\mathrm{Fe}$ & Mn & $\mathrm{Ni}$ & $\mathrm{Pb}$ & $\mathrm{Zn}$ \\
\hline 1 & 0.6279 & $<0.0006$ & $<0.01$ & $<0.007$ & 0.154 & $<0.002$ & $<0.002$ & $<0.008$ & $<0.0006$ \\
\hline 2 & $<0.02$ & $<0.0006$ & $<0.01$ & $<0.007$ & 0.2207 & 0.0374 & $<0.002$ & $<0.008$ & $<0.0006$ \\
\hline 3 & 0.4117 & $<0.0006$ & 0.0582 & $<0.007$ & 0.3444 & 0.0308 & 0.002 & 0.0086 & 0.0057 \\
\hline 4 & 0.6195 & $<0.0006$ & $<0.01$ & $<0.007$ & 0.1304 & $<0.002$ & $<0.002$ & $<0.008$ & $<0.0006$ \\
\hline 5 & 1.006 & $<0.0006$ & 0.1482 & $<0.007$ & 0.409 & 0.0601 & 0.0025 & $<0.008$ & 0.003 \\
\hline 6 & 1.076 & $<0.0006$ & 0.1463 & $<0.007$ & 6.09 & 0.0581 & 0.0022 & $<0.008$ & 0.0021 \\
\hline 7 & $<0.02$ & $<0.0006$ & 0.0652 & $<0.007$ & 0.352 & 0.138 & 0.0027 & $<0.008$ & $<0.0006$ \\
\hline 8 & $<0.02$ & $<0.0006$ & $<0.01$ & $<0.007$ & 0.0019 & $<0.002$ & $<0.002$ & 0.0116 & $<0.0006$ \\
\hline 9 & 0.247 & $<0.0006$ & 0.1841 & $<0.007$ & 0.4078 & $<0.002$ & $<0.002$ & 0.0145 & 0.0071 \\
\hline 10 & $<0.02$ & $<0.0006$ & $<0.01$ & $<0.007$ & $<0.01$ & 0.0541 & $<0.002$ & $<0.008$ & 0.0153 \\
\hline 11 & 1.844 & $<0.0006$ & 0.1955 & $<0.007$ & 9.208 & 0.227 & 0.0081 & 0.0213 & 0.0054 \\
\hline 12 & 0.632 & $<0.0006$ & $<0.01$ & $<0.007$ & 0.1572 & $<0.002$ & $<0.002$ & $<0.008$ & $<0.0006$ \\
\hline 13 & 0.261 & $<0.0006$ & 0.1973 & $<0.007$ & 0.481 & $<0.002$ & $<0.002$ & 0.0197 & 0.009 \\
\hline 14 & 0.252 & $<0.0006$ & 0.1921 & $<0.007$ & 0.421 & $<0.002$ & $<0.002$ & 0.0185 & 0.0082 \\
\hline 15 & $<0.02$ & $<0.0006$ & 0.0207 & $<0.007$ & 0.0691 & $<0.002$ & $<0.002$ & $<0.008$ & 0.0419 \\
\hline 16 & 0.6209 & $<0.0006$ & $<0.01$ & $<0.007$ & 0.1421 & $<0.002$ & $<0.002$ & $<0.008$ & $<0.0006$ \\
\hline 17 & $<0.02$ & $<0.0006$ & 0.0762 & $<0.007$ & $<0.01$ & $<0.002$ & 0.0043 & $<0.008$ & $<0.0006$ \\
\hline 18 & $<0.02$ & $<0.0006$ & $<0.01$ & $<0.007$ & 0.1318 & $<0.002$ & 0.0024 & $<0.008$ & 0.0059 \\
\hline 19 & $<0.02$ & $<0.0006$ & $<0.01$ & $<0.007$ & 0.0836 & 0.0573 & $<0.002$ & $<0.008$ & 0.1736 \\
\hline 20 & $<0.02$ & $<0.0006$ & $<0.01$ & $<0.007$ & 0.2139 & 0.0353 & $<0.002$ & $<0.008$ & $<0.0006$ \\
\hline 21 & $<0.02$ & $<0.0006$ & 0.0065 & 0.0448 & $<0.01$ & 0.0124 & 0.002 & $<0.008$ & 0.0044 \\
\hline 22 & $<0.02$ & $<0.0006$ & $<0.01$ & $<0.007$ & 1.466 & $<0.002$ & $<0.002$ & $<0.008$ & $<0.0006$ \\
\hline 23 & 0.1168 & $<0.0006$ & 0.0946 & $<0.007$ & 0.5925 & 0.0602 & $<0.002$ & $<0.008$ & $<0.0006$ \\
\hline 24 & 0.6029 & $<0.0006$ & 0.0666 & $<0.007$ & 0.0669 & $<0.002$ & $<0.002$ & $<0.008$ & $<0.0006$ \\
\hline 25 & 0.6395 & $<0.0006$ & 0.0974 & $<0.007$ & 0.1909 & $<0.002$ & $<0.002$ & 0.0091 & $<0.0006$ \\
\hline 26 & $<0.02$ & $<0.0006$ & 0.1813 & $<0.007$ & 0.12 & 0.0833 & $<0.002$ & $<0.008$ & 0.0098 \\
\hline 27 & $<0.02$ & $<0.0006$ & 0.0247 & $<0.007$ & 0.06869 & $<0.002$ & $<0.002$ & $<0.008$ & 0.0402 \\
\hline 28 & 1.664 & $<0.0006$ & 0.1687 & $<0.007$ & 9.899 & 0.2155 & 0.0078 & 0.0198 & 0.0042 \\
\hline 29 & 3.153 & $<0.0006$ & 0.1351 & $<0.007$ & 4.484 & 0.1739 & 0.01 & 0.0103 & $<0.0006$ \\
\hline 30 & $<0.02$ & $<0.0006$ & $<0.01$ & $<0.007$ & 0.241 & 0.0371 & $<0.002$ & $<0.008$ & $<0.0006$ \\
\hline 31 & $<0.02$ & $<0.0006$ & $<0.01$ & $<0.007$ & $<0.01$ & 0.1821 & $<0.002$ & 0.0151 & 0.0039 \\
\hline 32 & $<0.02$ & $<0.0006$ & 0.0842 & $<0.007$ & $<0.01$ & $<0.002$ & 0.0048 & $<0.008$ & $<0.0006$ \\
\hline 33 & $<0.02$ & $<0.0006$ & $<0.01$ & $<0.007$ & $<0.01$ & 0.1721 & $<0.002$ & 0.0121 & 0.0037 \\
\hline A.d & 0.371 & $<0.0006$ & 0.1296 & $<0.007$ & 1.856 & 0.0349 & $<0.002$ & 0.0045 & $<0.0006$ \\
\hline I.c & $<0.02$ & $<0.0006$ & $<0.01$ & $<0.007$ & 0.0964 & $<0.002$ & $<0.002$ & 0.0113 & $<0.002$ \\
\hline
\end{tabular}


The majority of samples (70\%) are characterized by assemblage I ( 3 sulphate salts). They represent intermediate stages of the groundwater chemistry evolution, which reflects that the chemistry of this water is due to the leaching and dissolution of terrestrial salts during the surface and subsurface runoff. About $30 \%$ of groundwater samples characterized by assemblage II represent an advanced groundwater chemistry evolution. Presence of $\mathrm{MgCl}_{2}$ and $\mathrm{MgSO}_{4}$ reflects that these waters are influenced by the dissolution of the marine salts from the Eocene limestone plateau.

\subsection{Mechanism Controlling Groundwater Chemistry}

Water rock interaction, evaporation and precipitation processes are the main processes that can generate the solutes in the groundwater (Mackenzie \& Garrells, 1965). A Gibbs plot (Gibbs, 1970) (Figure 7) reflects that there are two group of groundwater samples. The firist group is consists of the majority of the groundwater samples (82\%). This group is coincided with the evaporation dominance, indicating the influence of the evaporation processes on the groundwater chemistry during the surface runoff before the aquifer recharge. The second group (18\% of the groundwater samples) is located in the rock dominance end member zone reflect rock weathering source.

The hydrochemical relations are used for identifying the influence of evaporate dissolution, silicate or carbonate weathering on the groundwater chemistry (Figure 8). The relation between $\mathrm{Ca} / \mathrm{Na}$ vs $\mathrm{Mg} / \mathrm{Na}$ (meq/l) shows that most of the $\mathrm{Mg}^{2+}$ is derived from weathering of the silicate minerals with the influence of the evaporation processes (Figure 8(a)). The relation between TDS vs $\mathrm{Ca}^{2+} / \mathrm{Mg}^{2+}$ shows that the groundwater samples, which have TDS values lower than 1600 $\mathrm{mg} / \mathrm{l}$, have $\mathrm{Ca}^{2+} / \mathrm{Mg}^{2+}$ values $>1$. It indicates that the dissolution of calcite is the main controlling factor. The dissolution of dolomite is the main controlling factor where the groundwater samples of TDS more than $1600 \mathrm{mg} / \mathrm{l}$ have $\mathrm{Ca} / \mathrm{Mg}<$ 1 (Figure 8(b)). The scatter plot between $\mathrm{Cl}^{-} \mathrm{vs} \mathrm{Ca}^{2+}+\mathrm{Mg}^{2+}$ (Figure 8(c)) shows

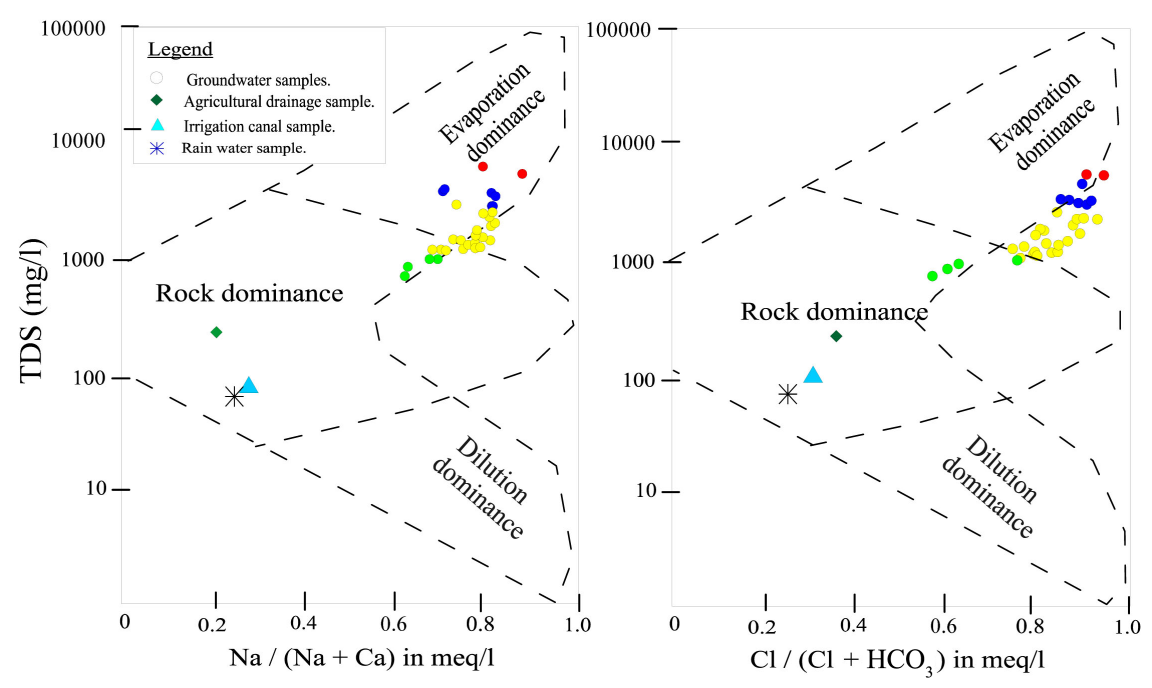

Figure 7. Gibbs diagram for the groundwater in Qasab basin. 


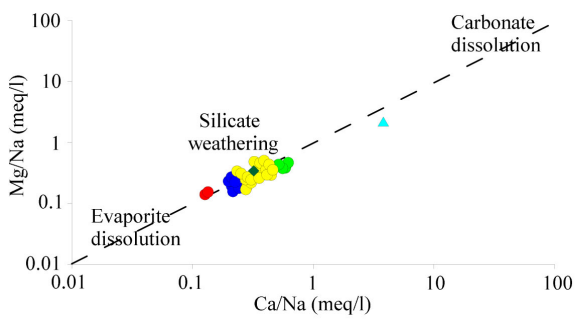

(a)

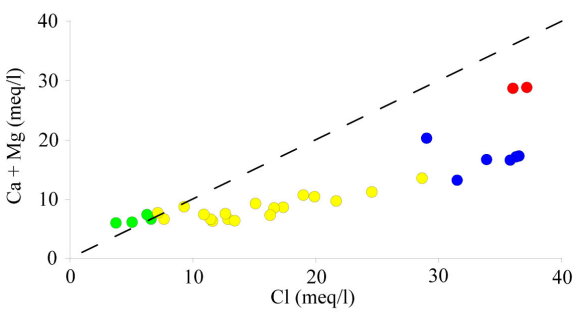

(c)

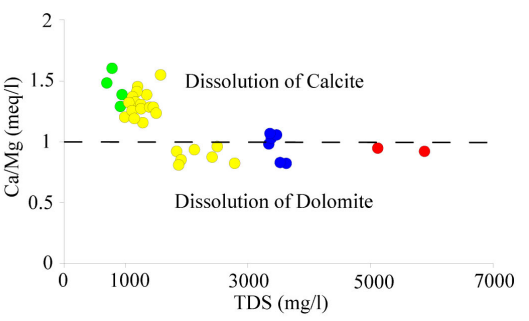

(b)

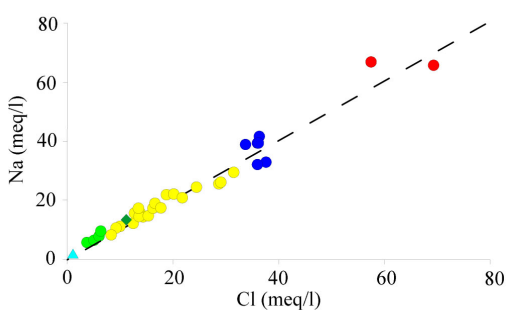

(d)

Figure 8. Hydrochemical ratios plots for the Pleistocene groundwater samples in Qasab basin.

that most of the groundwater samples located below the aquiline indicates the dominance of reverse ion exchange. The relation between $\mathrm{Na}^{+}$and $\mathrm{Cl}^{-}$(Figure 8(d)) shows that the majority of the groundwater samples (76\%) located above the aquiline reflected that the dominance of sodium from the silicate weathering. That may be attributed to the leaching and dissolution of terrestrial salts. The minority of the groundwater samples (24\%) have $\mathrm{rNa}^{+} / \mathrm{rCl}^{-}<1$. This is may be due to the leaching and dissolution of the marine deposits that may be transported by weathering. This weathering is from the Eocene limestone plateau beside the contribution of cation exchange processes between $\mathrm{Na}^{+}$and $\left(\mathrm{Ca}^{2+} \&\right.$ $\mathrm{Mg}^{2+}$ ).

The Chloro-Alkaline Indices (CAI) helps to identify the chemical composition changes in the study area. According to the calculation of CAI 1 and 2 which are suggested by Schoeller (1977), the majority of the computed average values of the CAI 1 and 2 for the groundwater samples (70\%) are negative values. They reflect the exchange of $\mathrm{Ca}^{2+}$ and $\mathrm{Mg}^{2+}$ from water with $\mathrm{Na}^{+}$and $\mathrm{K}^{+}$from rocks (Reverse cation exchange), where $30 \%$ of samples are positive values. They reflect the exchange of $\mathrm{Na}^{+}$and $\mathrm{K}^{+}$from water with $\mathrm{Ca}^{2+}$ and $\mathrm{Mg}^{2+}$ from rocks. This is may be due to presence of clay minerals (Figure 9).

The hydrochemical profile attempt (Figure 10) is made to identify the spatial variation of the groundwater chemical composition throw its flow path, in the direction from the Northeast to the Southwest from the upstream to the downstream of Wadi Qasab. There are considerable variations in the chemical composition of the groundwater. Due to variations in water occurrence, rock properties and recharge source as follows; the hydrochemical profile pass through 10 wells along the concerned aquifer in Wadi Qasab. The profile shows that approximate stability in the chemical composition from the upstream to the downstream before the rapid increase in the TDS and chemical composition in the 


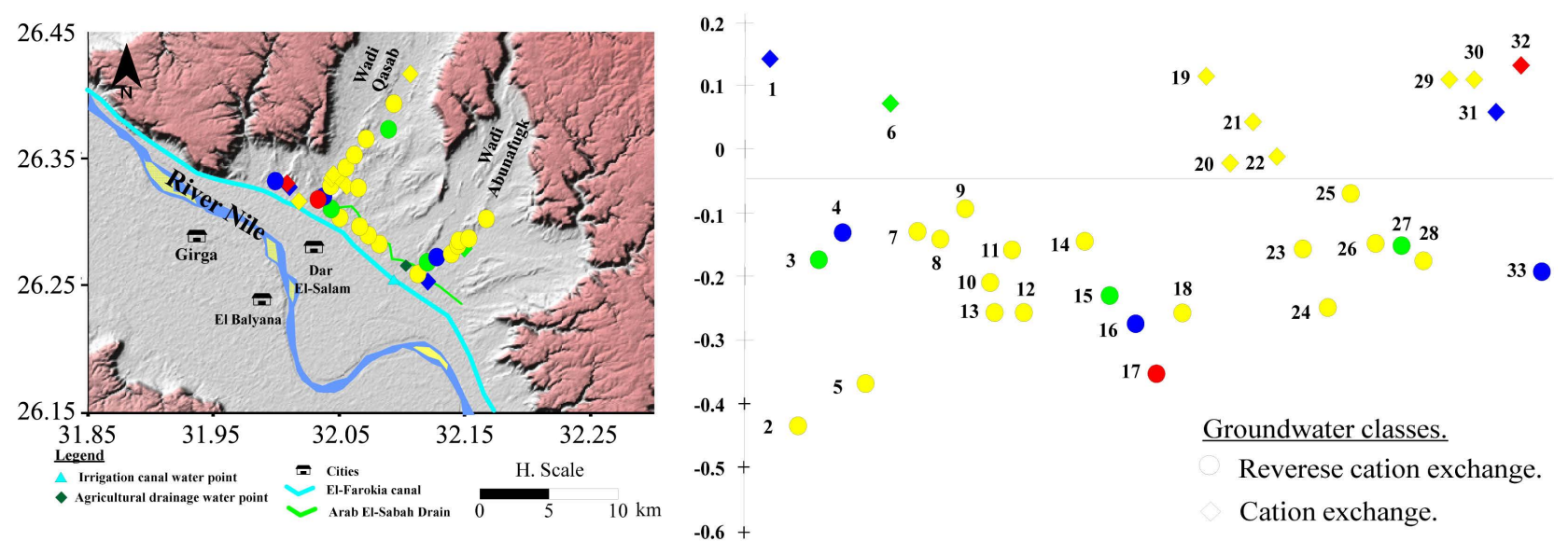

Figure 9. The classification of base cation exchange for the Pleistocene groundwater in Qasab basin.

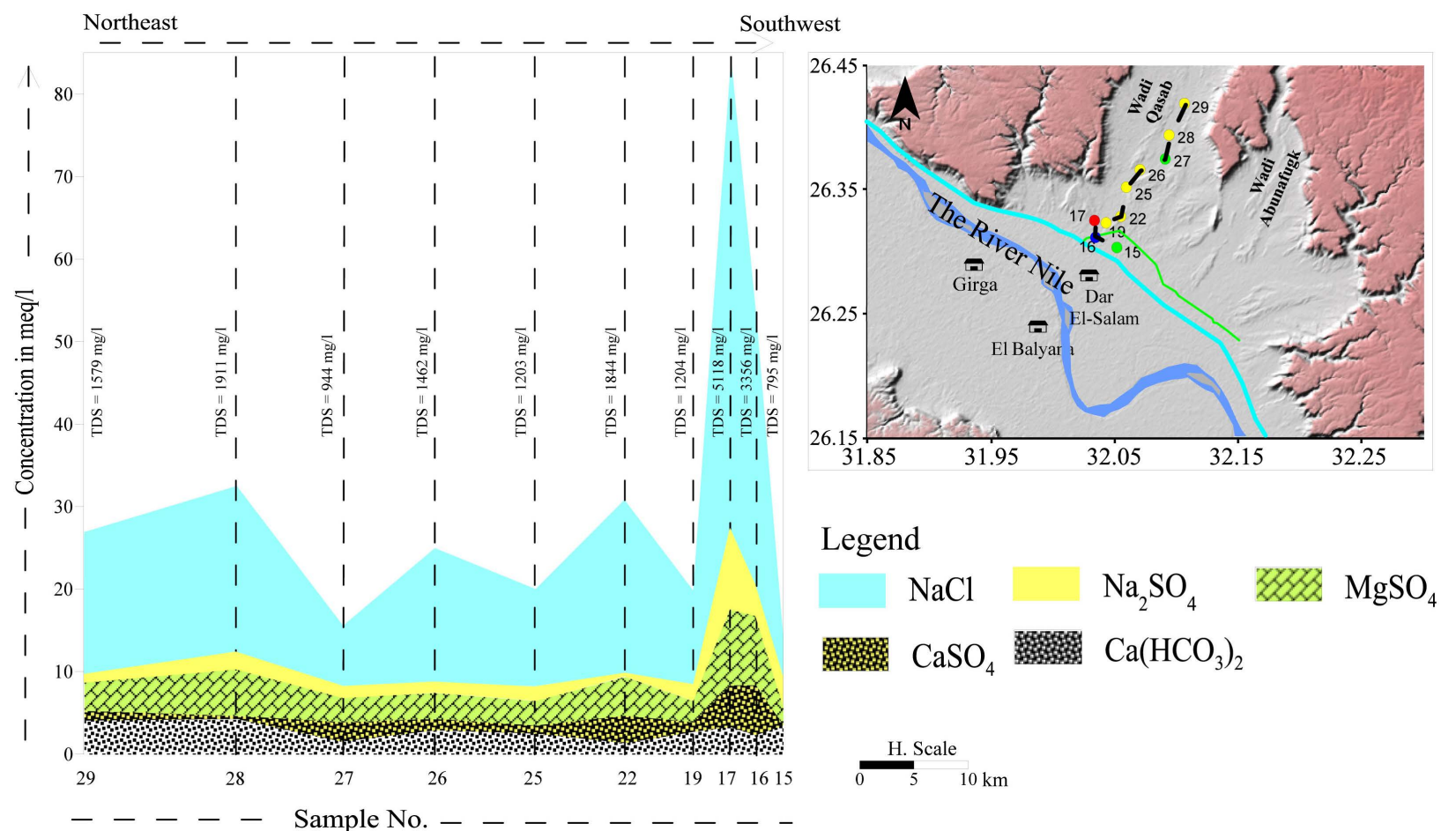

Figure 10. Hydrochemical profile of groundwater samples from Northeast to Southwest through the groundwater flow direction in Wadi Qasab.

well (No., 17). This may be due to the Pliocene clay mineral. The high decrease of the TDS value and the chemical composition in the end of the profile (well No., 15) is due to the influence of the fresh water recharge from the surface water seepage. It reflects the decrease of the concentration of chloride and sulphate salts and the increase of the $\mathrm{Ca}\left(\mathrm{HCO}_{3}\right)_{2}$ salt.

\subsection{Statistical Analysis}

\section{Coefficient Correlation $(R)$}

Correlation analysis is one of the statistical tools used for indicating which 
ions control the water salinization (Zeng \& Rasmussen, 2005). In the study area strong correlations $(>0.7)$ have been observed between EC and TDS with $\mathrm{Ca}^{2+}$, $\mathrm{Mg}^{2+}, \mathrm{Na}^{+}, \mathrm{SO}_{4}^{2-}$ and $\mathrm{Cl}^{-}$. This indicates that EC, TDS are controlled by these ions (Table 3 ). The ion exchange of the primary salts and the leaching or dissolution processes of the secondary salts are the main processes that controlling the Pleistocene groundwater salinization. These are due to the geological formations in the study area. A high positive correlation between $\mathrm{Na}^{+}$and $\mathrm{Cl}^{-}$suggests that mixing of groundwater with two different compositions (fresh and saline) and a strong relationship with $\mathrm{SO}_{4}^{2-}$ and $\mathrm{Cl}^{-}$may be due to the influence of the evaporation processes (Kumar et al., 2014). The strong correlation between $\mathrm{Ca}^{2+}$ and $\mathrm{SO}_{4}^{2-}$ suggests the dissolution processes of gypsum mineral.

\section{Cluster Analysis}

The results of Q-mode of HCA for the groundwater samples depend on the position of the cases on the Dendrogram (Figure 11). It shows 2 major clusters (cluster 1 and cluster 2 ) and 2 subdivisions of cluster 1 (cluster $1_{\mathrm{a}}$ and cluster $1_{\mathrm{b}}$ ). The groundwater samples which belongs to cluster 1 reflect the TDS values less than $5000 \mathrm{mg} / \mathrm{l}$ ( $94 \%$ of groundwater samples) reflect the same sources of the groundwater chemistry. Cluster 1 is divided in to two sub clusters. Sub cluster 1a reflects samples with TDS values less than $3000 \mathrm{mg} / \mathrm{l}$ (76\% of groundwater samples). These samples located closed to the watershed area or influenced by recharge from freshwater resources. Sub cluster $1 \mathrm{~b}$ which has TDS values ranges from 3000 to $5000 \mathrm{mg} / \mathrm{l}$ (18\% of groundwater samples). These samples located in the downstream of Qasab basin reflect that the relative increase in TDS values is due to the leaching and dissolution of terrestrial salts through groundwater flow path. Cluster 2 is characterized by high salinity groundwater TDS values $>5000$ (6\% of groundwater samples). These samples are located in the downstream of Qasab basin closed to the Eocene limestone plateau reflect the effect of the old marine deposits.

Table 3. Correlation matrix for hydrochemical data in Qasab basin.

\begin{tabular}{|c|c|c|c|c|c|c|c|c|c|c|c|}
\hline & $\mathrm{pH}$ & $\mathrm{EC}$ & TDS & $\mathrm{Ca}^{2+}$ & $\mathrm{Mg}^{2+}$ & $\mathrm{Na}^{+}$ & $\mathrm{K}^{+}$ & $\mathrm{CO}_{3}^{2-}$ & $\mathrm{HCO}_{3}^{-}$ & $\mathrm{SO}_{4}^{2-}$ & $\mathrm{Cl}^{-}$ \\
\hline $\mathrm{pH}$ & 1 & & & & & & & & & & \\
\hline $\mathrm{EC}$ & -0.224 & 1 & & & & & & & & & \\
\hline TDS & -0.236 & 0.999 & 1 & & & & & & & & \\
\hline $\mathrm{Ca}^{2+}$ & -0.249 & 0.909 & 0.903 & 1 & & & & & & & \\
\hline $\mathrm{Mg}^{2+}$ & -0.288 & 0.885 & 0.879 & 0.982 & 1 & & & & & & \\
\hline $\mathrm{Na}^{+}$ & -0.202 & 0.979 & 0.981 & 0.808 & 0.774 & 1 & & & & & \\
\hline $\mathrm{K}^{+}$ & -0.314 & 0.661 & 0.661 & 0.774 & 0.768 & 0.557 & 1 & & & & \\
\hline $\mathrm{CO}_{3}^{2-}$ & 0.459 & -0.324 & -0.322 & -0.301 & -0.364 & -0.289 & -0.416 & 1 & & & \\
\hline $\mathrm{HCO}_{3}^{-}$ & -0.203 & 0.160 & 0.155 & 0.277 & 0.330 & 0.091 & 0.227 & -0.084 & 1 & & \\
\hline $\mathrm{SO}_{4}^{2-}$ & -0.243 & 0.961 & 0.965 & 0.913 & 0.886 & 0.925 & 0.743 & -0.322 & 0.145 & 1 & \\
\hline $\mathrm{Cl}^{-}$ & -0.229 & 0.992 & 0.991 & 0.876 & 0.854 & 0.982 & 0.607 & -0.324 & 0.111 & 0.925 & 1 \\
\hline
\end{tabular}




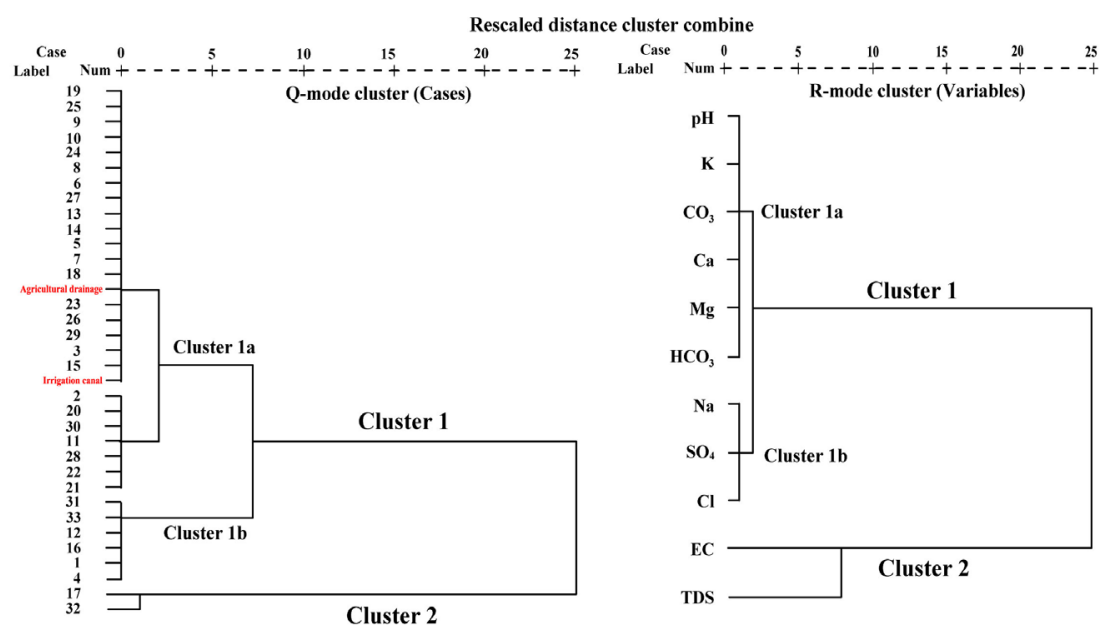

Figure 11. Dendrogram (Q-mode and R-mode) for the Pleistocene groundwater in the Qasab basin.

R-mode cluster reflects two main cluster. They reflect the interaction between variables (cluster 1 and cluster 2). Cluster 1 is divided in to two sub clusters (cluster 1a and cluster 1b). Sub cluster 1a reflects the correlation between $\mathrm{pH}$, $\mathrm{Ca}^{2+}, \mathrm{Mg}^{2+}, \mathrm{K}^{+}, \mathrm{CO}_{3}^{2-}$ and $\mathrm{HCO}_{3}^{-}$ions. This may indicate that the salinization may be due to dissolution of carbonate salts (aragonite, calcite and dolomite), where Sub-cluster $1 \mathrm{~b}$ reflects good correlation between $\mathrm{Na}^{+}, \mathrm{Cl}^{-}$and $\mathrm{SO}_{4}^{2-}$. This correlation may indicate that the source of the groundwater salinization in Qasab basin is due to the leaching and dissolution of chloride salts (halite) and sulphate salts (gypsum). Cluster 2 shows the correlation between EC and TDS.

\subsection{Stable Isotopes}

The stable isotopes content in the groundwater provides good insights about the main recharge and salinization sources (Eissa et al., 2013). According to the stable isotopes $\left(\delta^{2} \mathrm{H} \%\right.$ and $\delta^{18} \mathrm{O} \%$ o) values for the water resources in Qasab basin (Table 4 and Figure 12), two groundwater clusters can be identified in the $\delta^{2} \mathrm{H} \%$ vs $\delta^{18} \mathrm{O} \%$ plot (Figure 12(a)) reflects different groundwater origin and recharge sources:

Recent alluvium aquifer (group A): The groundwater samples of this group are enriched with the isotopic signature of $\delta^{18} \mathrm{O}$ and $\delta^{2} \mathrm{H}$. This group has positive $\delta^{18} \mathrm{O} \%$ values which range from 0.9 to 5.5 and $\delta^{2} \mathrm{H} \%$ from 17.2 to 54 . The groundwater samples are plotted more close to the isotopic signature representing surface water (irrigation canal water, agricultural drainage water and the old Nile before Aswan High Dam construction (Awad et al., 1994)). These varied values reflected the recent recharge (last decade) from the surface water leakage (irrigation canal water, agricultural drainage) and the River Nile floods before Aswan High Dam construction. The scatter plot for Group A gives the regression line of equation $\delta^{2} \mathrm{H} \% \mathrm{o}=8.93 \delta^{18} \mathrm{O} \% \mathrm{o}+2.86$. The deviation from the Global Meteoric Water Line (GMWL) (Craig, 1961) reflects the evaporation influence occurred before the recharge processes. 


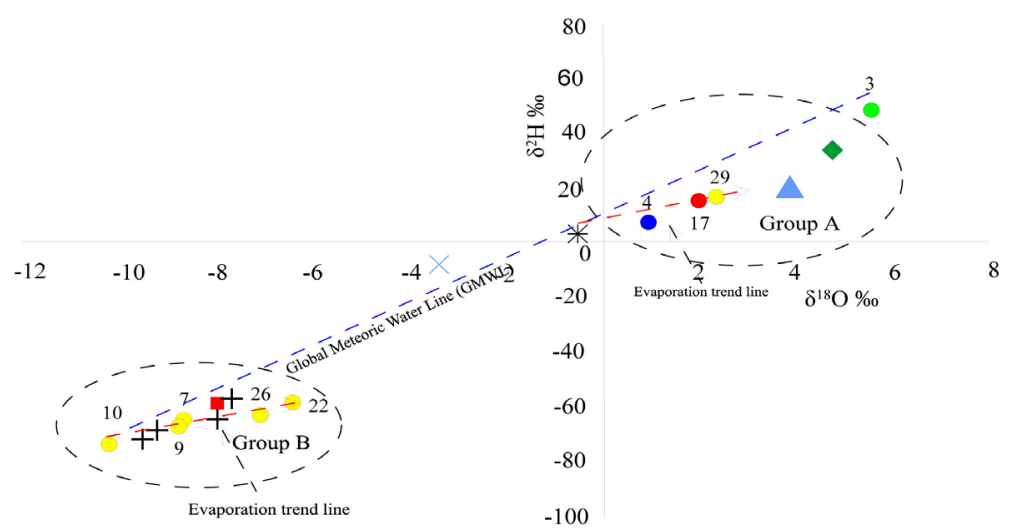

(a)

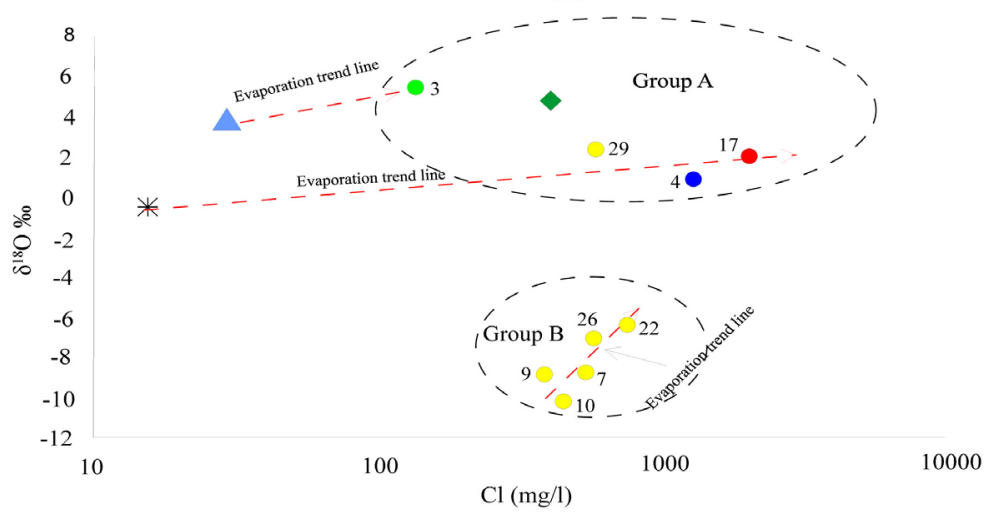

(b)

Legend

Groundwater samples Agricultural drainage sample $\Delta$ Irrigation Canal sample + Eastern desert paleo water

- Nubian sandstone water sample (Wadi Laqita) $\quad \times$ Egypt Rainwater $\quad$ 米 Old Nile water

Figure 12. (a) $\delta^{2} \mathrm{H} \%$ vs $\delta^{18} \mathrm{O} \%$ values for water resources; (b) Change of $\delta^{18} \mathrm{O} \%$ vs $\mathrm{Cl}$ $(\mathrm{mg} / \mathrm{l})$ values for water resources associated with different salinization processes (I.A.E.A., 1981) in Qasab basin, Eastern, Egypt.

Table 4. Isotopic composition of water samples in Qasab basin.

\begin{tabular}{ccc}
\hline Sample No. & $\delta^{18} \mathrm{O} \%$ & $\delta^{2} \mathrm{H} \%$ \\
\hline 3 & 5.5 & 47 \\
4 & 0.9 & 7 \\
7 & -8.7 & -67 \\
9 & -8.8 & -68 \\
10 & -10.2 & -74 \\
22 & -6.4 & -59 \\
26 & -7.1 & -64 \\
29 & 2.3 & 16 \\
17 & 2.1 & 15 \\
Agricultural drainage & 4.7 & 33 \\
Irrigation canal & 3.9 & 21 \\
Paleo Nile (Awad et al., 1994) & -0.6 & 4.3 \\
Rain (Sultan et al., 2011) & -3.5 & -8.9 \\
\hline
\end{tabular}


Old alluvium aquifer (group B): The groundwater samples of this group have a relatively depleted isotopic signature than group $\mathrm{A}$. This group reflects a palaeo recharge source; where the $\delta^{18} \mathrm{O}$ varies from $-10.1 \%$ to $-6.4 \%$ and $\delta^{2} \mathrm{H}$ and from $-74 \%$ o to $-59 \%$. The scatter plot for Group B gives the regression line of the equation $\delta^{2} \mathrm{H} \% 0=3.58 \delta^{18} \mathrm{O} \%$ - 36.88, it is deviated from the global meteoric line (GMWL) (Craig, 1961) that the groundwater samples influenced by evaporation processes. This group is plotted closer to the isotopic signature of the Nubian sandstone groundwater in Wadi Laqita $\delta^{2} \mathrm{H} \%$ o $=-68.2, \delta^{18} \mathrm{O} \% \mathrm{o}=$ -9.7 (Sherif et al., 2019) located Southern Qasab basin. These negative values were derived from a paleo-precipitation that occurred many thousands of years ago during the pluvial time (Ahmed, 2008). This confirms that, this group is charged from the upward leakages from the Nubian sandstone aquifer through deep seated faults (Figure 2). The upward leakage of groundwater phenomena has been reported in Wadi Qena basin (Hussien et al., 2016), and Wadi El-Assyuti located in the southern and Northern of Qasab basin; respectively (Sultan et al., 2007).

The relation between Chloride vs $\delta^{18} \mathrm{O} \%$ or for the groundwater samples in the study area (Figure 12(b)) indicates that the salinization source of both of the two groups is due to the leaching process. Throughout the runoff and dissolution process inside the aquifer with influence of evaporation prior to the recharge process occurs.

\subsection{Inverse Geochemical Modeling}

In order to delineate the origin of the groundwater mineralization, saturation indices (Aragonite, Calcite, Dolomite, Gypsum, and Halite), the results of saturation indices reflects positive values with regard to aragonite, calcite and dolomite for the majority of the groundwater samples (Table 5). This reflected the geological origin from the carbonate weathering. These samples suggested the saturation of these minerals. The relation between EC $(\mu \mathrm{S} / \mathrm{cm})$ and SI values in (Figure 13) for the groundwater samples reflects that the EC values are not

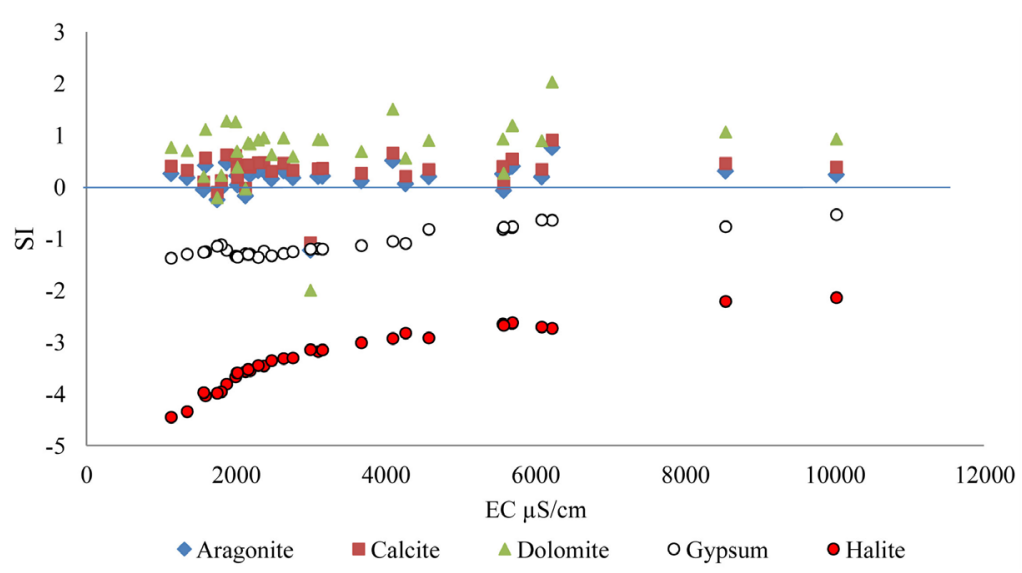

Figure 13. The relation between the SI of minerals in the Pleistocene ground water samples and the electrical conductivity (EC) $\mu \mathrm{s} / \mathrm{cm}$. 
Table 5. Summary of mass transfer for selected inverse geochemical models.

\begin{tabular}{|c|c|c|c|c|c|c|c|c|c|c|c|}
\hline No. & Aragonite & Calcite & Dolomite & Gypsum & Halite & No. & Aragonite & Calcite & Dolomite & Gypsum & Halite \\
\hline \multicolumn{12}{|c|}{ Saturation indices for water samples } \\
\hline 1 & 0.4 & 0.54 & 1.18 & -0.79 & -2.65 & 19 & 0.22 & 0.36 & 0.69 & -1.35 & -3.6 \\
\hline 2 & 0.51 & 0.66 & 1.5 & -1.05 & -2.93 & 20 & 0.06 & 0.21 & 0.56 & -1.1 & -2.83 \\
\hline 3 & 0.26 & 0.4 & 0.77 & -1.38 & -4.45 & 21 & 0.12 & 0.26 & 0.69 & -1.14 & -3.02 \\
\hline 4 & 0.4 & 0.54 & 1.19 & -0.77 & -2.63 & 22 & -1.23 & -1.08 & 0.68 & -1.2 & -3.15 \\
\hline 5 & 0.48 & 0.62 & 1.28 & -1.22 & -3.82 & 23 & 0.31 & 0.46 & 0.95 & -1.29 & -3.32 \\
\hline 6 & 0.42 & 0.56 & 1.11 & -1.25 & -4.04 & 24 & 0.29 & 0.43 & 0.85 & -1.31 & -3.54 \\
\hline 7 & 0.33 & 0.47 & 0.96 & -1.24 & -3.47 & 25 & 0.04 & 0.19 & 0.38 & -1.36 & -3.6 \\
\hline 8 & 0.24 & 0.38 & 0.83 & -1.3 & -3.56 & 26 & 0.16 & 0.3 & 0.63 & -1.33 & -3.36 \\
\hline 9 & 0.46 & 0.6 & 1.26 & -1.34 & -3.68 & 27 & -0.05 & 0.09 & 0.2 & -1.27 & -3.98 \\
\hline 10 & -0.17 & -0.03 & -0.04 & -1.3 & -3.57 & 28 & 0.21 & 0.36 & 0.91 & -1.21 & -3.16 \\
\hline 11 & 0.21 & 0.35 & 0.92 & -1.19 & -3.19 & 29 & 0.18 & 0.32 & 0.59 & -1.25 & -3.31 \\
\hline 12 & 0.25 & 0.4 & 0.93 & -0.82 & -2.65 & 30 & 0.2 & 0.34 & 0.9 & -0.82 & -2.92 \\
\hline 13 & -0.02 & 0.12 & 0.22 & -1.12 & -3.97 & 31 & 0.77 & 0.91 & 2.03 & -0.65 & -2.74 \\
\hline 14 & -0.25 & -0.1 & -0.21 & -1.15 & -3.99 & 32 & 0.24 & 0.38 & 0.93 & -0.54 & -2.14 \\
\hline 15 & 0.18 & 0.33 & 0.7 & -1.3 & -4.35 & 33 & 0.2 & 0.34 & 0.89 & -0.64 & -2.71 \\
\hline 16 & -0.07 & 0.08 & 0.26 & -0.78 & -2.68 & drain & 0.47 & 0.62 & 1.37 & -1.23 & -3.61 \\
\hline 17 & 0.31 & 0.46 & 1.06 & -0.77 & -2.21 & canal & 0.29 & 0.44 & 0.77 & -2.06 & -6.13 \\
\hline \multirow[t]{2}{*}{18} & 0.32 & 0.46 & 0.91 & -1.37 & -3.45 & rain & -2.04 & -1.89 & -3.73 & -2.93 & -7.04 \\
\hline & & \multicolumn{6}{|c|}{ Model 1} & \multicolumn{4}{|c|}{ Model 2} \\
\hline \multirow{2}{*}{\multicolumn{2}{|c|}{ Model }} & Initial & final & \multicolumn{2}{|c|}{ Initial } & \multicolumn{2}{|c|}{ final } & \multicolumn{2}{|c|}{ Initial } & \multicolumn{2}{|c|}{ final } \\
\hline & & 10 & 7 & \multicolumn{2}{|c|}{10} & & 2 & \multicolumn{2}{|c|}{ Nile water } & \multicolumn{2}{|c|}{29} \\
\hline \multicolumn{2}{|c|}{ Aragonite } & \multicolumn{2}{|c|}{-0.22} & \multicolumn{4}{|c|}{-0.69} & \multicolumn{4}{|c|}{2.10} \\
\hline \multicolumn{2}{|c|}{ Dolomite } & \multicolumn{2}{|c|}{-0.42} & \multicolumn{4}{|c|}{-0.29} & \multicolumn{4}{|c|}{-1.03} \\
\hline \multicolumn{2}{|c|}{ Gypsum } & \multicolumn{2}{|c|}{-0.09} & \multicolumn{4}{|c|}{-0.08} & \multicolumn{4}{|c|}{-2.54} \\
\hline \multicolumn{2}{|c|}{ Halite } & \multicolumn{2}{|c|}{-2.52} & \multicolumn{4}{|c|}{-3.57} & \multicolumn{4}{|c|}{-15.7} \\
\hline \multicolumn{2}{|c|}{ Evaporation factor } & & 0 & & & & & & & & \\
\hline & E & & 1 & & & & & & & & \\
\hline
\end{tabular}

-Ve: means dissolution; +Ve: means precipitation; $\mathrm{F}_{\mathrm{E}}$ : fraction evaporation loss.

considered influencing factors for the SI of aragonite, calcite and dolomite. However, they are clearly considered influencing factors. In the case of gypsum and halite, they reflect the direct increase of SI values with EC in the low EC values $(<4000 \mu \mathrm{S} / \mathrm{cm})$ before the relative stability in the relationship.

Aragonite, dolomite, gypsum, and halite minerals were included in the Netpath models as primary interactive phase, where $\mathrm{Ca}^{2+}, \mathrm{Mg}^{2+}, \mathrm{Na}^{+}, \mathrm{SO}_{4}^{2-}, \mathrm{Cl}^{-}$ were introduced into the model as constrains. The results of the Netpath software for the mass balance transfer along the flow path reflect the evolution of the groundwater along its flow path direction from the upstream to the downstream of Wadi Qasab. Two models were assumed in this study, the first model is for 
palaeo water and the second is for the samples that are originated from the runoff before Aswan High Dam construction with some influences from the irrigation canal and agricultural drainage. The reaction models are accepted according to the comparison of the evaporation factor that is estimated from Net path model and the fraction evaporation loss $\left(\mathrm{F}_{\mathrm{E}}\right)$ that is estimated from isotope the mas balance equation (Gonfiantini, 1986) (Table 5). The first model assumes that the initial water is the Pleistocene water (sample No., 10) with TDS value $1235 \mathrm{mg} / \mathrm{l}$ and the final water is Pleistocene water (sample Nos. 7 and 22) with TDS values 1379 and $1844 \mathrm{mg} / \mathrm{l}$. The model result reflects the dissolution of 0.22 and $0.69 \mathrm{mmol}$ of aragonite, $0.42,0.29$ of dolomite, $0.09,0.08 \mathrm{mmol}$ of gypsum and 2.52, $3.57 \mathrm{mmol}$ of halite. The second model assumes that the initial water is the Nile water with TDS $221 \mathrm{mg} / \mathrm{l}$ and the final water is Pleistocene water (sample No., 29) with TDS value $1579 \mathrm{mg} / \mathrm{l}$. The model result reflects the dissolution of $1.03 \mathrm{mmol}$ of dolomite, $2.54 \mathrm{mmol}$ of gypsum and $15.7 \mathrm{mmol}$ of halite. These models reflect that the salinity source of the groundwater samples is due to the leaching and dissolution processes of carbonate, sulphate and chloride salts during the runoff processes and water rock interaction inside the aquifer.

\subsection{Groundwater Assessment for Irrigation Purposes}

The irrigation water quality index (IWQI) for the groundwater samples is calculated (Table 6) in order to evaluate the groundwater for irrigation purposes. IWQI

Table 6. Irrigation water quality index and SAR values for the water resources in Qasab basin.

\begin{tabular}{cccccccc}
\hline No. & IWQI & Class & SAR & No. & IWQI & Class & SAR \\
\hline 1 & 30 & Medium & 19.1 & 19 & 35.5 & Medium & 10.9 \\
2 & 26 & Medium & 14.0 & 20 & 26.5 & Medium & 16.3 \\
3 & 34.5 & Medium & 4.8 & 21 & 30.5 & Medium & 14.7 \\
4 & 30.5 & Medium & 19.8 & 22 & 30.5 & Medium & 13.4 \\
5 & 33 & Medium & 7.1 & 23 & 35 & Medium & 11.8 \\
6 & 33.5 & Medium & 6.8 & 24 & 35 & Medium & 11.1 \\
7 & 35 & Medium & 9.4 & 25 & 35.5 & Medium & 11.0 \\
8 & 35.5 & Medium & 10.2 & 26 & 31.5 & Medium & 12.5 \\
9 & 35 & Medium & 9.0 & 27 & 33.5 & Medium & 6.7 \\
10 & 35.5 & Medium & 9.9 & 28 & 24.5 & Medium & 13.8 \\
11 & 24.5 & Medium & 13.3 & 29 & 31.5 & Medium & 12.9 \\
12 & 30.5 & Medium & 19.4 & 30 & 30.5 & Medium & 11.6 \\
13 & 33.5 & Medium & 7.5 & 31 & 30.5 & Medium & 12.1 \\
14 & 33.5 & Medium & 7.5 & 32 & 30.5 & Medium & 22.8 \\
15 & 37.5 & High & 4.1 & 33 & 26.5 & Medium & 12.2 \\
16 & 30.5 & Medium & 19.2 & Agricultural drainage & 35.5 & Medium & 9.0 \\
17 & 30.5 & Medium & 32.1 & Irrigation Canal & 40 & High & 0.6 \\
18 & 31.5 & Medium & 13.3 & & & & \\
\hline
\end{tabular}

IWQI: Irrigation Water Quality Index, SAR: Sodium Adsorption Ratio. 
values for the groundwater samples in the study area range from 24.5 to 37.5 with mean value 31.7 . This value reflects that a one water point is only classed as highly suitable for irrigation purposes (well No., 15). The majority of the ground water samples are classes as moderately suitable for irrigation. These values reflect that the Pleistocene groundwater samples are suitable for irrigation of good and high salt tolerance plants. The IWQI values of the irrigation canal and the agricultural drainage are 40 and 35.5 respectively. These results reflect the high suitability of the irrigation canal and moderate suitability of the agricultural drainage of the irrigation purposes.

The groundwater samples are plotted on the USSL diagram (Richards, 1954). This diagram developed a procedure for irrigation water classification, relating on a graphic analysis basis, where EC is plotted against SAR. The USSL diagram shows that $6 \%$ of the groundwater samples are located in $\mathrm{C}_{3}-\mathrm{S}_{1}$ (Table 6 \& Figure 14). These samples indicate low alkalinity with high salinity of water. They reflect that this water can be used for irrigation in all types of soils with little danger of exchangeable sodium. $24 \%$ of samples are located in $\mathrm{C}_{3}-\mathrm{S}_{2}$ and $\mathrm{C}_{4}-\mathrm{S}_{2}$ fields reflecting medium sodality and high salinity. This type of water cannot be used in fine grained soils where the drainage is restricted due to the accumulation of salts in the root zones of crops. This leads to salinity and soil clogging crisis. This type of water is satisfactory only for irrigation of plants with good tolerance. It may be used in coarse-textured types of soils or organic types of soils with good permeability. $15 \%$ of samples fallen in $\mathrm{C}_{3}-\mathrm{S}_{3}$ class show high salinity water and high sodium water. They reflect that this type of water is satisfactory only for irrigation of plants with good tolerance with the adequate drainage system. $30 \%$ of samples are located in $\mathrm{C}_{4}-\mathrm{S}_{3}$ and $\mathrm{C}_{4}-\mathrm{S}_{4}$ fields class reflect very high salinity water and very high sodium water. They are suitable only for irrigation of very salt-tolerant crops due to the high SAR values under very

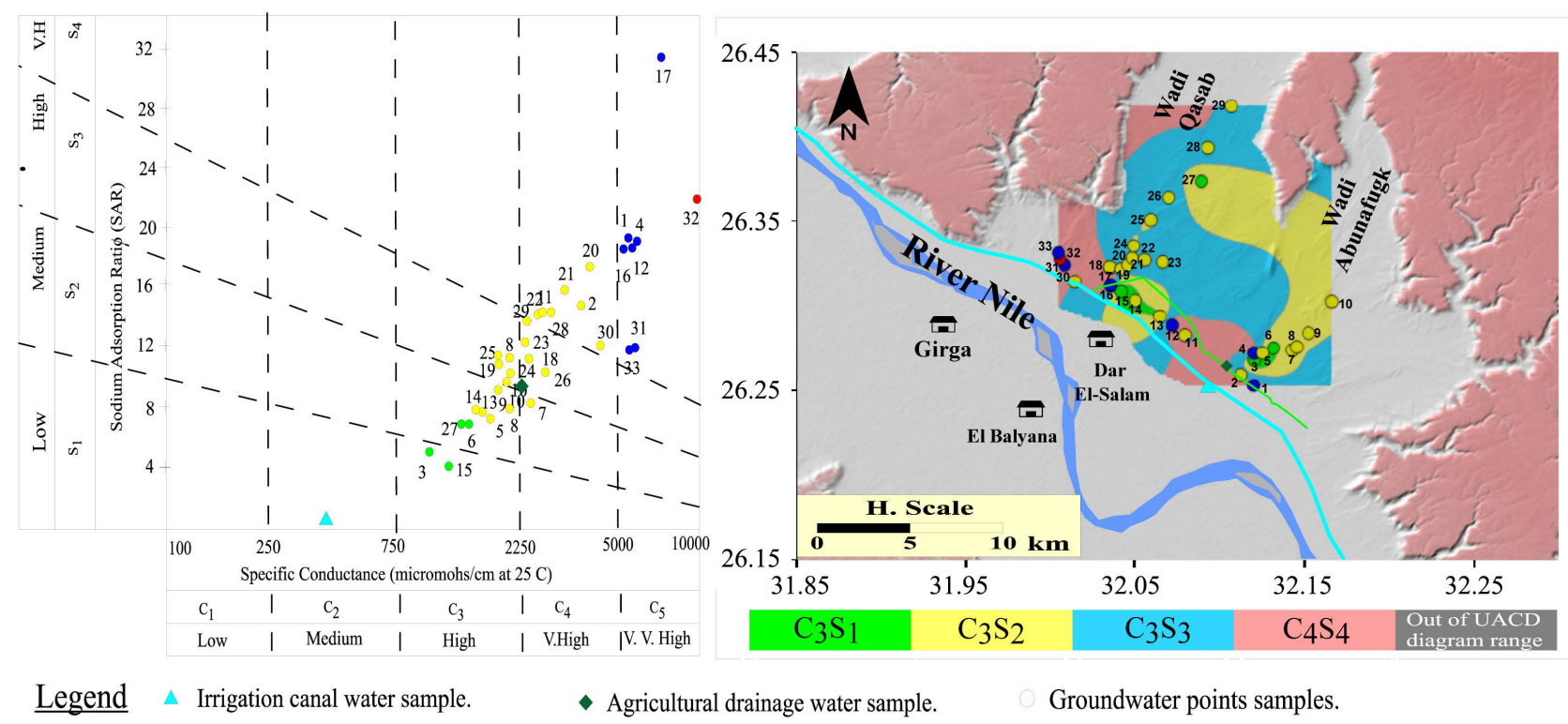

Figure 14. Classification of water samples for irrigation uses, with respect to EC and SAR, USSL diagram. 
Table 7. Recommended limits for constituents in reclaimed water for irrigation in $\mathrm{mg} / \mathrm{l}$ (Rowe \& Abdel-Magid, 1995).

\begin{tabular}{cccccccccc}
\hline Constituent & $\mathrm{Al}$ & $\mathrm{Cd}$ & $\mathrm{Cr}$ & $\mathrm{Cu}$ & $\mathrm{Fe}$ & $\mathrm{Mn}$ & $\mathrm{Ni}$ & $\mathrm{Pb}$ & $\mathrm{Zn}$ \\
\hline Long-term use & 5 & 0.01 & 0.1 & 0.2 & 5 & 0.2 & 0.2 & 5 & 2 \\
Short-term use & 20 & 0.05 & 1 & 5 & 20 & 10 & 2 & 10 & 10 \\
\hline
\end{tabular}

special circumstances with permeable soil type. Good drainage system and the irrigation must be applied in excess to provide considerable leaching. $25 \%$ of samples located in $\mathrm{C}_{5}-\mathrm{S}_{4}$ field reflect high saline water. This type is only suitable for very salt tolerant crops with bad influence on the plant productivity.

The evaluation of the irrigation water based on trace elements concentrations according to recommended limits for constituents in reclaimed water for irrigation (Rowe \& Abdel-Magid, 1995) (Table 7). Both of the surface and the Pleistocene groundwater samples are safe for irrigation purposes for short-term use in respect to $\mathrm{Al}, \mathrm{Cd}, \mathrm{Cr}, \mathrm{Cu}, \mathrm{Fe}, \mathrm{Mn}, \mathrm{Ni}, \mathrm{Pb}$ and $\mathrm{Zn}$. All the Pleistocene groundwater samples and the surface water samples are safe for irrigation purposes for long-term use in respect $\mathrm{Al}, \mathrm{Cd}, \mathrm{Cr}, \mathrm{Cu}, \mathrm{Fe}, \mathrm{Mn}, \mathrm{Ni}, \mathrm{Pb}$ and $\mathrm{Zn} .27 \%$ of the Pleistocene groundwater samples and the agricultural drainage sample are unsuitable for long-term irrigation purposes in respect to $\mathrm{Cr}$ concentration. 9\% of the Pleistocene groundwater samples are unsuitable for long-term irrigation purposes in respect to Fe concentration. In spite of this type of water is not toxic to plants in aerated soils, but it lead to soil acidification and loss of phosphorus and molybdenum. $6 \%$ of the Pleistocene groundwater samples are unsuitable for long-term irrigation purposes in respect to $\mathrm{Mn}$ concentration. This type of water is toxic to a number of crops in acid soils.

\section{Conclusion}

The main objective of this study is to identify the hydrochemical characteristics, the processes controlling the groundwater quality and the groundwater origin as well as assessment of the main groundwater aquifers for irrigation purposes in Qasab basin in the Eastern Desert fringes of Sohag Governorate region. The integration between statistical analysis, environmental stable isotopes, and invers geochemical modeling suggest variations in the groundwater aquifer's hydrochemical characteristics as well as the different background of recharge origin. Hydrochemical results demonstrate that the majority of samples are brackish water. The salinity of the groundwater increase towards the south-west direction is influenced by the interaction of groundwater and the geological materials as well as the contribution of the seepage from the surface water systems (Irrigation canal \& agricultural drain). Groundwater mineralization is controlled by the evaporation processes during the surface runoff before the aquifer recharge, and few samples are influenced by rock weathering source. The wide variation of Fe concentration suggests that its content is controlled by several intermixed processes. The significant positive relation between Fe and Mn indicates the Fe source may 
be attributed to rock weathering. The positive correlation between $\mathrm{Fe}$ with $\mathrm{Al}, \mathrm{Cr}$ and $\mathrm{Pb}$ may be attributed to the agricultural activities, which reflects another source of groundwater contamination with respect to $\mathrm{Fe}$.

The statistical analysis indicates that the ion exchange of the primary salts and the leaching or dissolution processes of the secondary salts as well as the anthropogenic activities are the main processes controlling the salinization of the Pleistocene groundwater. R-mode cluster reflects the interaction between variables; this may indicate that the salinization may be due to dissolution of carbonate salts (aragonite, calcite and dolomite), beside the leaching and dissolution of chloride salts (halite) and sulphate salts (gypsum).

The isotopic signature $\left({ }^{2} \mathrm{H}\right.$ and $\left.{ }^{18} \mathrm{O}\right)$ for the water resources represents two forms of groundwater; the first of them is the groundwater wells located in the downstream of Wadi Qasab affected by the recent surface water leakage (irrigation canal water, agricultural drainage). The second is palaeowater tapping because the Pleistocene aquifer is recharged from the upward leakages from the Nubian sandstone aquifer through deep seated faults. The inverse geochemical model (NETPATH) assumes two models. The first model assumes that both of the initial and the final water are Pleistocene water. This model reflects the dissolution of aragonite, dolomite, gypsum and halite. The second model assumes that the initial water is the Nile water and the final water is Pleistocene water. The model result reflects the dissolution of dolomite, gypsum and halite. These models reflect that the salinity source of the groundwater samples is due to the leaching and dissolution processes of carbonate, sulphate and chloride salts during the runoff processes and water rock interaction inside the aquifer.

The evaluation of water resources for irrigation purposes reflects that the groundwater samples are suitable for irrigation of good and high salt tolerance plants. The Pleistocene groundwater samples are suitable for irrigation of plants range from good to high salt tolerance plants. $6 \%$ of the groundwater samples can be used for irrigation in all types of soils with little danger of exchangeable sodium. $24 \%$ of samples cannot be used in fine grained soils and satisfactory only for irrigation of plants with good tolerance. $15 \%$ of groundwater samples are satisfactory only for irrigation of plants with good tolerance with the adequate drainage system. $30 \%$ of the groundwater samples are suitable only for irrigation of very salt-tolerant crops. $25 \%$ of the groundwater samples are only suitable for very salt tolerant crops with bad influence on the plant productivity. All the Pleistocene groundwater samples and the surface water samples are safe for irrigation purposes for long-term use in respect $\mathrm{Al}, \mathrm{Cd}, \mathrm{Cr}, \mathrm{Cu}, \mathrm{Fe}, \mathrm{Mn}, \mathrm{Ni}, \mathrm{Pb}$ and $\mathrm{Zn.} \mathrm{27 \%} \mathrm{of} \mathrm{the} \mathrm{Pleistocene} \mathrm{groundwater} \mathrm{samples} \mathrm{and} \mathrm{the} \mathrm{agricultural} \mathrm{drainage}$ sample are unsuitable for long-term irrigation purposes in respect to Cr concentration. 9\% of the Pleistocene groundwater samples are unsuitable for long-term irrigation purposes in respect to $\mathrm{Fe}$ concentration. $6 \%$ of the Pleistocene groundwater samples are unsuitable for long-term irrigation purposes in respect to $\mathrm{Mn}$ concentration.

Based on the finding results of this research, drilling groundwater wells tap- 
ping the Nubian sandstone aquifer should provide additional sustainable groundwater resources for the study area. The subsurface lithology and groundwater exploration should be carried out through geophysical investigation and pore hole test well in order to provide clear image about the situation of such deep aquifer.

\section{Conflicts of Interest}

The author declares no conflicts of interest regarding the publication of this paper.

\section{References}

Abdel Moneim, A. A. (2005). Overview of the Geomorphological and Hydrogeological Characteristics of the Eastern Desert of Egypt. Hydrogeology Journal, 13, 416-425. https://doi.org/10.1007/s10040-004-0364-y

Abdel Moneim, A. A., Seleem, E. M., Zeid, S. A., AbdelSamie, S. G., Zaki S., \& AbuEl-Fotoh, A. (2015). Hydrogeochemical Characteristics and Age Dating of Groundwater in the Quaternary and Nubian Aquifer Systems in Wadi Qena, Eastern Desert, Egypt. Sustainable Water Resources Management, 1, 213-232. https://doi.org/10.1007/s40899-015-0018-3

Abdulhady, Y., Zaghlool, E., \& Gedamy, Y. (2018). Assessment of the Groundwater Quality of the Quaternary Aquifer in Reclaimed Areas at the Northwestern El-Minya Governorate-Egypt, Using the Water Quality Index. International Journal of Recent Scientific Research, 9, 23033-23047.

Ahmed, A. A. (2009). Using Lithologic Modeling Techniques for Aquifer Characterization and Groundwater Flow Modeling of the Sohag Area, Egypt. Hydrogeology Jour nal, 17, 1189-1201. https://doi.org/10.1007/s10040-009-0461-Z

Ahmed, A. A., \& Ali, M. H. (2009). Hydrochemical Evolution and Variation of Groundwater and Its Environmental Impact at Sohag, Egypt. Arabian Journal of Geosciences, 4, 339-352. https://doi.org/10.1007/s12517-009-0055-Z

Ahmed, M. (2008). Geochemical and Isotopic Characteristics of Quaternary Aquifer in Sohag District, Upper Egypt. Arab Journal of Nuclear Science and Applications, 41, 129-146.

Ahmed, S. M. (1980). Geology of the Area East and Southeast of Sohag. M.Sc. Thesis, Assiut: Assiut University.

Appelo, C., \& Postma, D. (2005). Geochemistry, Groundwater and Pollution (2nd ed.). Rotterdam: Balkema.

Attia, F. A. R., Allam, M. N., \& Amer, A. W. (1986). A Hydrologic Budget Analysis for the Nile Valley in Egypt. Groundwater, 24, 453-459. https://doi.org/10.1111/j.1745-6584.1986.tb01023.x

Awad, M. A., Farid, M. S., \& Hamza, M. S. (1994). Studies on the Recharge of the Aquifer Systems in the Southern Systems in the Southern Portion of the Nile Delta Using Radio Isotopes and Hydrochemistry. Isotope and Radiation Research, 26, 17-25.

Ayers, R. S., \& Westcot, D. W. (1985). Water Quality for Agriculture. FAO Irrigation and Drainage Paper No. 29, Rev. 1, Rome: U.N. Food and Agriculture Organization,.

Cloutier, V., Lefebvre, R., Therrien, R., \& Savard, M. (2008). Multivariate Statistical Analysis of Geochemical Data as Indicative of the Hydrogeochemical Evolution of Groundwater in a Sedimentary Rock Aquifer System. Journal of Hydrology, 353, 294-313. https://doi.org/10.1016/j.jhydrol.2008.02.015 
Coleman, M. L., Shepherd, T. J., Durham, J. J., Rouse, J. E., \& Moore, G. R. (1982). Reduction of Water with Zinc for Hydrogen Isotope Analysis. Analytical Chemistry, 54, 993-995. https://doi.org/10.1021/ac00243a035

Craig, H. (1961). Isotopic Variations in Meteoric Waters. Science, 133, 1702-1703. https://doi.org/10.1126/science.133.3465.1702

Davis, J. C. (2002). Statistics and Data Analysis in Geology. New York: John Wiley \& Sons Inc.

Egyptian General Petroleum Corporation (E.G.P.C.) (1987). A Geological Map of Egypt. 1:500000, 20 Sheets. Bani Suef, Assiut and South Sinai Sheets.

Eissa, M., Ali M., Zaghlool, E., \& Stash, O. S. (2019). Hydrochemical and Stable Isotopes Indicators for Detecting Sources of Groundwater Contamination Close to Bahr El-Baqar Drain, Eastern Nile Delta, Egypt. Journal Water Science, 33, 54-64. https://doi.org/10.1080/11104929.2019.1635346

Eissa, M., Thomas, M., Hershey, L., Dawoud, M., Pohll, G., Dahab, K., \& Shabana A. (2013). Geochemical and Isotopic Evolution of Groundwater in the Wadi Watir Watershed, Sinai Peninsula, Egypt. Environmental Earth Sciences, 71, 1855-1869. https://doi.org/10.1007/s12665-013-2588-4

Epstein, S., \& Mayeda T. (1953). Variation of $\mathrm{O}^{18}$ Content of Water from Natural Sources. Geochimica et Cosmochimica Acta, 4, 213-224. https://doi.org/10.1016/0016-7037(53)90051-9

Farrag, A., Megahed, H. A., ElSayed, E. A., \& El Sayed, A. M. (2015). Evaluation of Groundwater Aquifers Potentiality to Delineate Temporal Changes in Land Use in Nag-Hammadi Area, Qena, Egypt, Using GIS and Remote Sensing Techniques. 8th International Conference on the Geology of Africa, Assiut, Egypt, November 2015, iv-27-iv-41.

Freeze, R., \& Cherry, J. (1979). Groundwater (p. 604). Englewood Cliffs, NJ: Prentice Hall, Inc.

Gad, A. W. (2017). Water Scarcity in Egypt: Causes and Consequences. IIOABJ, 8, 40-47.

Ganoup El-Wadi Petroleum Company (1994). Geological Report of the Balyana-1 Well. Cairo, Egypt: The Egyptian General Petroleum Corporation.

Gat, J. (1981). Groundwater, Stable Isotopes Hydrology, Deuterium and Oxygen 18 in the Water Cycle (p. 223). Technical Report Series No. 210, Vienna: I.A.E.A.

Ghazala, H., Ibraheem, M., Haggag, M., \& Lamees, M. (2018). An Integrated Approach to Evaluate the Possibility of Urban Development around Sohag Governorate, Egypt, Using Potential Field Data. Arabian Journal of Geosciences, 11, 193-212. https://doi.org/10.1007/s12517-018-3535-1

Gibbs, R. J. (1970). Mechanisms Controlling World Water Chemistry. Science, 170, 1088-1090. https://doi.org/10.1126/science.170.3962.1088

Gomaa, A. A. (2006). Hydrogeological and Geophysical Assessment of the Reclaimed Areas in Sohag, Nile Valley, Egypt. Ph.D. Thesis, Cairo: Ain Shams University.

Gonfiantini, R. (1986). Environmental Isotopes in Lake Studies. In P. Fritz, \& J.-Ch. Fontes (Eds.), Handbook of Environmental Isotope Geochemistry (pp. 113-168). Amsterdam: Elsevier. https://doi.org/10.1016/B978-0-444-42225-5.50008-5

Huang, G., Sun, J., Zhang, Y., Chen, Z., \& Liu, F. (2013). Impact of Anthropogenic and Natural Processes on the Evolution of Groundwater Chemistry in a Rapidly Urbanized Coastal Area, South China. Science of the Total Environment, 463-464, 209-221. https://doi.org/10.1016/j.scitotenv.2013.05.078

Hussien, H. M., Kehew, A. E., Aggour, T., Korany, E., Abotalib, A. Z., Hassanein, A., \& 
Morsy, S. (2016). An Integrated Approach for Identification of Potential Aquifer Zones in Structurally Controlled Terrain: Wadi Qena Basin, Egypt. CATENA, 149, 73-85. https://doi.org/10.1016/j.catena.2016.08.032

International Atomic Energy Agency (I.A.E.A.) (1981). Stable Isotope Hydrology: Deuterium and Oxygen-18 in the Water Cycle. Monograph Prepared under the Aegis of the I.A.E.A./UNESCO Working Group on Nuclear Techniques in Hydrology of the International Hydrological Program, STI./DOC./10/210.

Issawi, B., Hassan, M. W., \& Osman, R. (1978). Geological Studies in the Area of Kom Ombo, Eastern Desert, Egypt. Annals of the Geological Survey of Egypt, 8, 187-235.

Kumar, S., Bharani, R., Magesh, N. S., Godson, P. S., \& Chandrasekar, N. (2014). Hydrogeochemistry and Groundwater Quality Appraisal of Part of South Chennai Coastal Aquifers, Tamil Nadu, India Using WQI and Fuzzy Logic Method. Applied Water Science, 4, 341-350. https://doi.org/10.1007/s13201-013-0148-4

Langmuir, D. (1997). Aqueous Environmental Geochemistry (p. 601). Englewood Cliffs, NJ: Prentice-Hall, Inc.

Lloyd, W., \& Heathcote, A. (1985). Natural Inorganic Hydrochemistry in Relation to Groundwater, an Introduction. Oxford: Clarendon Press.

Mackenzie, F., \& Garrels, I. (1965). Silicates-Reactivity with Sea Water. Science, 150, 57-58. https://doi.org/10.1126/science.150.3692.57

Marković, T., Karlović, I., Perčec Tadić, M., \& Larva, O. (2020). Application of Stable Water Isotopes to Improve Conceptual Model of Alluvial Aquifer in the Varaždin Area. Water, 12, 379. https://doi.org/10.3390/w12020379

Melegy, A. A., Shaban, A. M., Hassaan, M. M., \& Salman, S. A. (2013). Geochemical Mobilization of Some Heavy Metals in Water Resources and Their Impact on Human Health in Sohag Governorate, Egypt. Arabian Journal of Geosciences, 7, 4541-4552. https://doi.org/10.1007/s12517-013-1095-y

Omar, M. E. D., \& Moussa, A. M. (2016). Water Management in Egypt for Facing the Future Challenges. Journal of Advanced Research, 7, 403-412. https://doi.org/10.1016/j.jare.2016.02.005

Omer, A. A. (1996). Geological, Mineralogical and Geochemical Studies on the Neogene and Quaternary Nile Basin Deposits, Qena-Assiut Stretch, Egypt. Ph.D. Thesis, Qena: South Valley University, Egypt.

Piper, A. M. (1953). A Graphic Representation in the Geochemical Interpretation of Groundwater Analysis. American Geophysical Union Transactions, 25, 914-928. https://doi.org/10.1029/TR025i006p00914

Plummer, L. N., Prestemon, E. C., \& Parkhurst, D. L. (1994). An Interactive Code (NETPATH) for Modelling Net Geochemical Reactions along a Flow Path. Version 2, U.S. Geological Survey, Water Resources Investigation Report 94-4169.

Richards, L. (1954). Diagnosis and Improvement of Saline and Alkali Soils. United States Salinity Laboratory, Vol. 60, Agriculture Handbook, Washington DC: US Department of Agriculture.

RIGW Egypt (1997). Hydrogeological Maps of Egypt, Scale 1:100,000. Egypt: Water Research Center, Ministry of Public Works and Water Resources.

Rowe, D. R., \& Abdel-Magid, I. M. (1995). Handbook of Wastewater Reclamation and Reuse. Boca Raton, FL: CRC Press.

Said, I., Merz, C., Salman, S. A. E.-R., Schneider, M., \& Winkler, A. (2020). Identification of Hydrochemical Processes Using Multivariate Statistics in a Complex Aquifer System of Sohag Region, Egypt. Environmental Earth Sciences, 79, Article No. 169. 
https://doi.org/10.1007/s12665-020-08913-8

Said, R. (1960). Planktonic Foraminifera from the Thebes Formation, Luxor, Egypt. Micropaleontology, 6, 227-286. https://doi.org/10.2307/1484234

Said, R. (1975). The Geological Evolution of the River Nile. In F. Wendorf, \& A. F. Marks (Eds.), Problems in Prehistory of Northern Africa and the Levant. Dallas, TX: Southern Methodist University Press.

Said, R. (1981). The Geological Evaluation of the River Nile. New York: Springer Verlag. https://doi.org/10.1007/978-1-4612-5841-4

Schoeller, H. (1977). Geochemistry of Groundwater. In Groundwater Studies-An International Guide for Research and Practice (Chap. 15, pp. 1-18). Paris: UNESCO.

Sherif, M. I., Sultan, M., \& Sturchio, N. C. (2019). Chlorine Isotopes as Tracers of Solute Origin and Age of Ground Waters from the Eastern Desert of Egypt. Earth and Planetary Science Letters, 510, 37-44. https://doi.org/10.1016/j.epsl.2018.12.035

Singh, C. K., Kumar, A., Shashtri, S., Kumar, A., Kumar, P., \& Mallick, J. (2017). Multivariate Statistical Analysis and Geochemical Modeling for Geochemical Assessment of Groundwater of Delhi, India. Journal of Geochemical Exploration, 175, 59-71. https://doi.org/10.1016/j.gexplo.2017.01.001

Spandana, M. P., Suresh, K. R., \& Prathima, B. (2013). Developing an Irrigation Water Quality Index for Vrishabavathi Command Area. International Journal of Engineering Research \& Technology (IJERT), 2, 821-830.

Sulin, V. A. (1946). Oil Water in the System of Natural Groundwater. Gostopichezdat, Moscow USSR, 30, 37-45.

Sultan, M., Metwally, S., Milewski, A., Becker, D., Ahmed, M., Sauck, W., Soliman, F., Sturchio, N., \& Yan, E. (2011). Modern Recharge to Fossil Aquifers: Geochemical, Geophysical, and Modeling Constraints. Journal of Hydrology, 403, 14-24. https://doi.org/10.1016/j.jhydrol.2011.03.036

Sultan, M., Yan, E., Sturchio, N., Wagdy, A., AbdelGelil, K., Becker, R., Manocha, M., \& Milewski, A. (2007). Natural Discharge: A Key to Sustainable Utilization of Fossil Groundwater. Journal of Hydrology, 335, 25-36. https://doi.org/10.1016/j.jhydrol.2006.10.034

Trabelsi, R., \& Zouari, K. (2019). Coupled Geochemical Modeling and Multivariate Statistical Analysis Approach for the Assessment of Groundwater Quality in Irrigated Areas: A Study from North Eastern of Tunisia. Groundwater for Sustainable Development, 8, 413-427. https://doi.org/10.1016/j.gsd.2019.01.006

US Salinity Laboratory Staff (1954). Diagnosis and Improvement of Saline and Alkali Soils (p. 160). US Department of Agriculture, Handbook No. 60.

World Health Organization (WHO) (2011). Guideline for Drinking Water Quality (4th ed.). Geneva: World Health Organization.

https://apps.who.int/iris/bitstream/handle/10665/44584/9789241548151_eng.pdf?seque $\underline{\text { nce }=1}$

Youssef, M. A., Omer, A. A., Ibrahim, M. S., \& Cawlfield, J. D. (2011). Geotechnical Investigation of Sewage Wastewater Disposal Sites and Use of GIS Land Use Maps to Assess Environmental Hazards: Sohag, Upper Egypt. Arabian Journal of Geosciences, 4, 719-733. https://doi.org/10.1007/s12517-009-0069-6

Zeng, X., \& Rasmussen, T. C. (2005). Multivariate Statistical Characterization of Water Quality in Lake Lanier, Georgia, USA. Journal of Environment Quality, 34, 1980-1991. https://doi.org/10.2134/jeq2004.0337 